Research Report No. 1/2008

\title{
Can Factory List Disclosure Improve Labor Practices in the Apparel Industry? A Case Study of Nike and Levi-Strauss
}

David J. Doorey

Follow this and additional works at: http://digitalcommons.osgoode.yorku.ca/clpe

\section{Recommended Citation}

Doorey, David J., "Can Factory List Disclosure Improve Labor Practices in the Apparel Industry? A Case Study of Nike and LeviStrauss" (2008). Comparative Research in Law \& Political Economy. Research Paper No. 1/2008.

http://digitalcommons.osgoode.yorku.ca/clpe/214 
David J. Doorey

Can Factory List Disclosure Improve Labor Practices in the Apparel Industry? A Case Study of Nike and Levi-Strauss

EDITORS: Peer Zumbansen (Osgoode Hall Law School, Toronto, Director, Comparative Research in Law and Political Economy, York University), J ohn W. Cioffi (University of California at Riverside), Lindsay Krauss (Osgoode Hall Law School, Toronto, Production Editor) 
CLPE Research Paper 01/2008

Vol. 04 No. 01 (2008)

\title{
David J. Doorey
}

\section{CAN FACTORY LIST DISCLOSURE IMPROVE LABOR Practices in the APPARel Industry? A CaSe Study OF NIKE AND LEVI-STRAUSS}

\begin{abstract}
How would multinational apparel companies and retailers react to a requirement to disclose the identity and address of the factories in their global supply chain? Could disclosure regulation of this sort cause management changes that could lead to improved labor practices in those factories? Disclosure regulation is a common tool in the arsenal of socalled "decentered" regulatory strategies, which emphasize ways that law can be used to guide and influence the private development of behavioral norms that are consistent with the state's policy objectives. The author traces the history of factory disclosure, and theorizes that mandatory factory list disclosure introduces into the management system a new "risk virus" that companies will seek to manage through systems changes that can ultimately lead to improvements on the factory floors. To explore this theory, the author conducted extensive interviews with senior executives of Nike, Inc. and Levi-Strauss, two companies that recently released their global factory lists "voluntarily". The research indicates that these companies prepared extensively for the moment of disclosure by significantly improving and investing in their global labor practices monitoring and inspection systems. Neither company identified any negative business effects from the factory disclosure, but both emphasized that the disclosure had facilitated greater collaboration within the industry emphasizing shared strategies to improve supply chain labor practices. These outcomes are potentially useful in the struggle to improve labor practices. Therefore, the author proposes factory list disclosure regulation as an attainable and relatively subtle use of law that might nevertheless contribute in meaningful ways to the challenge of improving working conditions around the world.
\end{abstract}

Keywords: labor practices, Nike, Levi-Strauss, multinational apparel companies, factory list disclosure, regulation 
JEL classification: J38, J50, J51, J58, K20, K31, M14, P33

Author Contact: David J. Doorey

York University

4700 Keele St.

Toronto, Ontario, Canada M3J 1P3

Email: ddoorey@yorku.ca 


\title{
CAN FACTORY LiSt Disclosure IMPRove LABOR PRACTICES IN THE APPAREL IndUSTRY? A CASE STUDY OF NIKE AND LEVI-STRAUSS ${ }^{1}$
}

\author{
David J. Doorey ${ }^{*}$
}

\section{INTRODUCTION}

Information disclosure regulation is experiencing a renaissance. This development parallels, indeed is part of, a more general interest in socalled "post modern" regulatory approaches to governance that concentrate on the role of the state and regulation as a facilitator of the development of normative standards of conduct by private actors. Appearing under monikers such as "responsive", "reflexive", "outsourced" and "decentered" regulation, or "new governance" and "third way" regulation, these approaches to regulation share an emphasis on the norm creating potential of private interactions - negotiations, conflicts, and compromises - between businesses and various state and non-state actors, including non-governmental organizations (NGOs), unions, shareholders, consumer groups, religious-based organization, and other

* Assistant Professor, York University, Toronto. This research is generously supported by a Research Fellowship from the Social Sciences and Humanities Research Council of Canada and the Helena Orton Memorial Fellowship of Osgoode Hall Law School. This paper was presented at the CRIMT Conference, "What Policies for a Global Era?", HEC Montreal, 2007.

${ }^{1}$ This paper draws on interviews with Michael Kobori, Vice President Corporate Code of Conduct, Levi-Strauss at his office in San Francisco in 2006 and Caitlin Morris, Director of Engagement and Integration, Labor Compliance Department, Nike, at Nike's Headquarters' in Beaverton, Oregon in 2006, as well as discussions and/or e-mail communications with: Neil Kearney, General Secretary, International Textile, Garment, and Leather Workers' Federation in Toronto, 2006; Bob Jeffcott and Lynda Yanz of the Maquila Solidarity Network, in Toronto, 2005 and 2006; Harvey Chan, Director, Ethical Sourcing, Mountain Equipment Co-op, in Toronto, 2007; and Patrick Neyts, VECTRA International, in Toronto, 2007. 
civil society organizations. ${ }^{2}$ Information disclosure regulation is an important tool in this approach to governance because it aims to influence private behavior indirectly, but towards the attainment of state-desired outcomes.

Disclosure regulation can inject new risks, like a virus, into management decision-making processes in the expectation that corporate leaders will seek to manage that risk in ways the state believes will further its policy objectives. Regulatory examples abound: disclosure of toxic emissions will cause companies to reduce emissions ${ }^{3}$; disclosure of executive salaries will cause compensation committees to impose salaries that are reasonable and fair $^{4}$; disclosure of racial and gender percentages of employees will discourage discriminatory employment practices; disclosure of the race of loan recipients will discourage racially discriminatory lending practices by lending institutions; ${ }^{5}$ disclosure of payments to foreign officials will discourage bribery ${ }^{6}$, and so on.

${ }^{2}$ This literature is discussed in greater detail in: David J. Doorey, Who Made That?: Influencing Foreign Labor Practices Through Domestic Disclosure Regulation, 43 Osgoode Hall L.J. 353 (2005). See also Julia Black, Decentring Regulation: Understanding the Role of Regulation and Self-Regulation in a 'Post-Regulatory' World, 53 Curr. Legal Probs. 103 (2001); Orel Lobel, The Renew Deal: The Fall of Regulation and the Rise of Governance in Contemporary Legal Thought, 89 Minn. L. Rev, 342 (2004).

${ }^{3}$ See the Emergency Planning and Community Right-to-Know Act, 42 U.S.C. $\$ \$ 11001-$ 50 (2005); William Pederson, Regulation and Information Disclosure: Parallel Universes and Beyond , 25 Harv. Envtl. L. Rev. 151, 151 (2001); M. Stephan, Environmental Information Disclosure Programs: They Work, But Why?, 83 Soc. Sci. Q. 190 (2002); R. Percival et al., Environmental Regulation: Law, Science, and Policy 624 ( $^{\text {nd }}$ ed. Little Brown \& Co 1996) (the theory behind the legislation was that the emissions information "would enable the public to put substantial pressure on companies to reduce emissions").

${ }^{4}$ See, e.g. E. Iacobucci, The Effects of Disclosure on Executive Compensation, 48 U. Toronto L.J. 489, 501 (1998).

${ }^{5}$ See the Home Mortgage Disclosure Act, 12 U.S.C. $\$ \S 2801-10$ (1994).

6 See the Foreign Corrupt Practices Act, 15 U.S.C. $\S 78$ (1998); H. L. Brown, Extraterritorial Jurisdiction Under the 1988 Amendments to the Foreign Corrupt Practices Act: Does the Government's Reach Exceed its Grasp?, 26 N.C.J. Int'l L. \& Com. Reg. 239 (2001). 
The underlying theory is the same in each instance: companies will reduce or refrain altogether from engaging in practices the state perceives as undesirable if they are forced to admit publicly that they are engaging in those practices. ${ }^{7}$ The reasons why law-makers expect this to be the case are complex and varied, but they usually include a belief that companies will be concerned that they will be punished financially if the information disclosed is deemed unacceptable to important stakeholders, such as customers and investors. The "science" of designing disclosure regulation is in knowing, or learning, whether the disclosure requirement will be perceived as a risk by the target of the regulation and, if so, how the target will then react.

This in turn requires the state to be an astute observer of the environment in which the target of the disclosure regulation operates. What motivates it? What are its vulnerabilities? With which other actors does it engage in cooperative or antagonistic relations, and how might those other actors put the new information disclosed to use in those engagements? By studying these sorts of questions, the state might be able to predict how certain actors will respond to a requirement to disclose information they would rather keep secret.

Recent proposals by NGOs for states to require apparel companies to disclose the precise name and address of every factory involved in the production of their products operate on the same basic model as these other disclosure models. The idea is that the apparel corporations will alter their behavior in useful ways in order to manage the perceived additional risk associated with a completely transparent supply chain. The main risk, simply stated, is that antagonistic actors will use that information to investigate factory conditions and then publicize labor abuses discovered in them with the aim of influencing consumer and investor markets in ways unfavorable to the apparel company.

\footnotetext{
${ }^{7}$ For work discussing labor practices and transparency, see C. Sabel, D. O'Rourke, A. Fung, Can We Put an End to Sweatshops? (Beacon Press 2001); Cynthia Williams, The SEC and Corporate Social Transparency 112 Harvard L. Rev. 1197 (1999); Doorey, supra note 2; K. Kolben, Integrative Linkage: Combining Public and Private Regulatory Approaches in the Design of Trade and Labor Regimes, 48 Harv. Int'1 L.J. 203 (2007).
} 
Since no state presently requires disclosure of global factory lists, we lack sufficient data to test this theory. However, we do have hypothesis's. Advocates of factory disclosure have a robust and sophisticated vision of how mandatory factory disclosure would contribute to the struggle to improve labor conditions in factories supplying the global apparel industry. And we now also have a proxy of sorts, because several large apparel and sportswear corporations have recently disclosed their factory lists "voluntarily", under sustained pressure from NGOs and labor groups for years to take this step. This enables us to explore some important questions, such as: Why were these companies prepared to disclose their supplier list when most companies continue to assert that this information is of immeasurable business value? What management systems were implemented by these companies to manage and reduce the perceived risk of factory disclosure? What effects has factory disclosure had on the disclosing company, and on the industry more generally? Are there lessons for labor policy within the story of voluntary factory disclosure, and if so, what are they?

This paper begins to explore these questions. In Part I, I summarize the key normative assertions of advocates of mandatory factory disclosure, focusing on the ways in which factory disclosure is expected to positively influence the management of supply chain labor practices. Part II examines the origins of the factory disclosure movement, tracing its roots in the early 1990s to its modern day place in the NGO movement to influence labor practices in the global apparel industry. Drawing on interviews with senior corporate responsibility officials from each company, Part III then explores in detail how two industry leaders, Nike and Levi-Strauss, decided in 2005 to publicly release their global factory databases. Finally, in Part IV, I will explore the impact that factory disclosure has had to date on these companies and within the industry. I will conclude by assessing what lessons for the possibilities of factory disclosure regulation we might take from the voluntary factory disclosure at Nike and Levi-Strauss. Ultimately, I conclude that factory disclosure may induce reactions within companies that could benefit the governance of labor practices within the global apparel industry. My conclusion therefore is that factory disclosure deserves careful consideration as a labor policy in the future. 


\section{FACTORY DISClOSURE AND ITS INFLUENCE ON THE Governance OF SUPPLY CHaIN LABOR PRACTICES: THE THEORY}

In Canada, the principle advocate for factory disclosure has been a small, yet influential NGO called the Maquila Solidarity Network (MSN) based in Toronto, and a related organization for which MSN serves as Secretariat, the Ethical Trading Action Group (ETAG). ${ }^{8}$ In early 2001, ETAG sent a letter to Canada's Industry Minister proposing a change to the Regulations to the federal government's Textile Labelling Act that would require disclosure of the factory identify and address to be made available for all apparel goods sold in Canada. The proposal was to utilize the existing regulatory model, which already requires a variety of information to be disclosed on product labels (such as fibre content, the name of the dealer, and the country of origin). ${ }^{9}$ ETAG's proposal was for factories to be made publicly available on a government website by entering the "CA Number" on the label of the product. The website already exists, as does the CA Number identification system. ${ }^{10}$ The ETAG proposal sought merely to require one additional piece of information: factory name and address. ${ }^{11}$

\footnotetext{
${ }^{8}$ Several American-based organizations have pushed for factory disclosure, most notably the United Students Against Sweatshops (USAS), as described in Part II. Other American organizations that have proposed factory disclosure include: International Right to Know Campaign (http://www.irtk.org), the Global Corporate Sunshine Group (http://www.corporatesunshine.org), and the National Labor Committee (http://www.nlcnet.org).

${ }^{9}$ See Textile Labelling and Advertising Regulations, C.R.C., c. 1551, esp. ss. 11-12.

10 See Competition Bureau Canada CA Identification Number - FAQs, http://strategis.ic.gc.ca/app/cb/canumber/faqs.do;jsessionid=0000 NyX45Orf8yS79CVfOh 04dQf:vdd1lsjb?language=eng (last visited Nov 3, 2007).

${ }^{11}$ See Ethical Trading Action Group, Transparency and Disclosure: New Regulatory Tools to Challenge Sweatshop Abuses: Submission to Public Policy Forum's National Consultation on Textile Labelling (September 30, 2003), http://en.maquilasolidarity.org/sites/maquilasolidarity.org/files/ETAGTransparencyandDi sclosure.pdf.
} 
In 2002, Industry Canada ordered a public consultation to examine the proposal. In its submission, ETAG argued that a regulation requiring factory disclosure would have the following positive effects:

...factory disclosure regulation would be good for the Canadian apparel industry, as well as for garment workers that make its products, because it would encourage Canadian companies to become more knowledgeable about their supply chains, establish longer term business relationships with trusted suppliers, and better monitor labor practices in their supplier factories. ${ }^{12}$

These arguments are both intriguing and sophisticated from a regulatory perspective. The central premise of ETAG's argument is that disclosure regulation will provoke reactions within the management of the apparel companies, and that these reactions will ultimately contribute to a more positive environment for labor within the global supply chains. ETAG, and other supporters of mandatory factory disclosure, assume that factory disclosure will be interpreted by corporations as a risk, like a "virus" that needs to be managed and controlled. The strength of the virus lies in the threat that consumers (and investors) may be convinced to punish the apparel company, but empowering consumers is not the principal objective of factory disclosure. Rather, the primary objective is to empower NGOs and labor organizations in their engagements with multinational apparel companies.

Therefore, factory disclosure is about shifting the balance of power as between apparel companies and retailers (and to a lesser degree, the suppliers) and the many local and transnational advocacy networks ${ }^{13}$ engaged in pressuring these companies to effect positive change in labor practices. For example, ETAG wrote that factory disclosure would give social activists:

\footnotetext{
${ }^{12}$ Id. at 10 .

${ }^{13}$ See D. Trubek, J. Mosher, \& J. Rothstein, Transnationalism in the Regulation of Labor Relations: International Regimes and Transnational Advocacy Networks, 25 (4) Law \& Soc. Inquiry 1187 (2000) (discusses transnational advocacy networks in the labor sphere).
} 
...the capability to link particular abuses and particular struggles at southern factories to particular brands and articles of clothing. Canadian labor rights activists would be able to engage in practical and effective solidarity with workers who try to organize to improve conditions squeezing the company between workers organizing on one end and consumer organizing on the other.

Every claim by a corporation or a monitoring organization about conditions in a particular factory could more easily be independently investigated by coalitions of labor activists.

Unions and NGOs in the labor field have already shown themselves to be quite adept at organizing damaging public relations campaigns that target the sourcing apparel corporations when abusive factory conditions are discovered in a supplier factory. Factory disclosure would make it easier and cheaper to link factories to specific brands and to organize campaigns around these linkages. ${ }^{14}$ It is this risk that in theory would motivate the apparel corporations to pay greater attention to what is going on in their supplier factories. Advocates of factory disclosure predict that apparel corporations and factory owners would take a number of potentially useful steps in order to manage the factory disclosure "virus".

\section{A. ANTICIPATED RESPONSES BY APPAREL COMPANIES TO FACTORY LIST DISCLOSURE}

\section{1. "SelF" Learning About the SupPly Chain}

One obvious effect of mandatory factory disclosure is that it would cause companies to learn what factories they are using. This alone would be a useful contribution to the challenge to improving supply chain labor practices. Many companies still use sourcing agents and take a hands-off approach to the selection of their suppliers. As a result, as a spokesperson for the Retail Counsel of Canada ("RCC") conceded in 2002, "tracking

\footnotetext{
${ }^{14}$ H. Arthurs, Labor Law Without a State, 46 U. Toronto L.J. 1 (1995) (arguing that the many linkages in the modern global supply chain create multiple vulnerabilities for multinational corporations).
} 
clothing factories is almost impossible" for these companies. ${ }^{15}$ These companies may care significantly about design, fabric, stitch quantity, quality issues, and delivery deadlines, and may monitor these issues very closely, but they do not care who is making the product to their specifications.

Of course, if tracking factories is impossible, then so too is tracking labor conditions in those factories. Therefore, if the RCC position (as stated above) is an accurate depiction of the apparel industry in Canada, then the inescapable conclusion is that self-regulation of labor conditions in supplier factories is failing miserably. Advocates of factory disclosure point out that it is irresponsible for companies to ignore where their products are made and that if factory disclosure regulation could force companies to compile and maintain a list of factories, this alone would be a useful start and a good use of regulation.

\section{IMPROVED INTERNAL COMMUNICATION SYSTEMS AND BETTER FACTORY MONITORING}

Factory disclosure may also cause improved communications systems within the apparel corporations. The risk of being publicly associated with a "sweatshop" factory is increased with factory disclosure. Factory disclosure advocates believe this creates an incentive for apparel companies to implement more organized and thorough monitoring processes to limit the chances of horrific labor practices being discovered first by external actors. They believe also that it will cause companies to implement better information flow systems that enable quick communication up the information ladder to senior labor compliance personnel who possess both the incentive and the authority to implement measures to extinguish problems before they become potential public relations problems.

\section{ENCOURAGE LONGER TERM SUPPLIER CONTRACTS}

${ }^{15}$ Canadian Broadcasting Corporation, Cut it Out Campaign Focuses on Sweatshop Labor (27 March 2002), www.cbc.ca/consumers/market/files/home/cutitout/ (quoting Sharon Maloney, Retail Counsel of Canada; excerpt re CBC Marketplace broadcast produced by Erica Johnson). 
Factory disclosure may also discourage the particularly harmful practice of "cutting and running". This occurs when companies cut ties with a factory found to have been engaged in poor labor practices, rather than remaining but working to improve those practices. A key to improving labor practices in the apparel industry is to encourage longer term relationships between apparel companies and the supplier factories. Raising labor standards often requires financial and resource investment by factory owners who in turn require some assurance that these cost outlays will not be met with cancelled contracts as the apparel companies seek cheaper alternatives.

With a complete list of factories, labor activists can more effectively monitor the movement of supply contracts. For example, if workers at Factory $\mathrm{A}$ in Honduras organize a union and bargain improved conditions, observers can carefully track how particular apparel companies that use that factory react. If companies pull out, campaigns can be organized to pressure the company to return if the local workers believe that will help. At present, most companies are able to avoid this sort of scrutiny because tracking factory movement is extremely difficult. If labor advocates could use factory disclosure to pressure and embarrass companies that engage in "cut and run" sourcing strategies, then disclosure might encourage the apparel companies to forge longer term relationships with their suppliers. ${ }^{16}$

\section{Linking EmPloyee Evaluations to Labor Compliance MEASURES}

The increased risk of negative exposure associated with public factory disclosure may also cause apparel companies to integrate labor compliance measures into employee evaluation and compensation schemes. Some apparel companies now employ staff specifically responsible for monitoring labor practices in supplier factories. In other cases, sourcing employees are expected to protect the company's interests by pressuring

\footnotetext{
${ }^{16}$ MSN engaged in an effective campaign in 2000 that embarrassed The Hudson's Bay Company for its decision to pull contracts from a factory in Lesotho after labor abuses were discovered there. MSN awarded HBC its "Sweatshop Retailer of the Year Award" for its decision to "cut and run", while simultaneously praising The Gap, who responded to news of the abuses by maintaining its contract with the factory and to pressure the owners to improve their labor practices. See Doorey, supra note 2, at 403-404.
} 
supplier factories to comply with local laws or codes of conduct. Insofar as a company's human resource policies involve employee evaluations, it seems logical that the evaluation criteria for these sorts of employees would include some measurement of how well factories are performing in terms of labor compliance issues. This in turn might increase the incentive for those employees to be vigilant in their efforts to pressure suppliers to comply with labor standards.

\section{IMPROVED COMMUNICATIONS WITH STAKEHOLDERS AND COMPETITORS}

Another anticipated benefit of factory disclosure is that it will encourage greater engagement by companies with competitors and external actors, including labor-related NGOs. Factory disclosure could facilitate more investigations and external reviews of factory conditions by NGOs, unions, media, and academics, for instance, and because disclosure permits these external reviewers to easily link factories to brands, the belief is that the apparel companies will find themselves dialoguing with the external actors more frequently. Moreover, when supplier lists become public information, so that there are no secrets about which factories are being used by which company, the potential benefits of collaborating with competitors about shared problems will become more obvious. If seven apparel companies are sourcing from the same factory, there may be no need to conduct seven different internal audits if the companies can agree to share information and work together to design remediation problems.

\section{B. ANTICIPATED RESPONSE OF FACTORY OWNERS (CONTRACTORS) TO FACTORY LIST DISCLOSURE}

Factory disclosure may also influence the behavior of factory owners. Most suppliers desire contracts from major brands like Nike, Levis, and The Gap, for example. Suppliers that have contracts with these major companies will often advertise this fact as proof of their quality and reliability to attract new customers. Under a system of mandatory factory disclosure, suppliers to major brands are more likely to attract attention

from labor advocates. Factory owners who have an interest in preserving their contracts with the major apparel companies, will wish to avoid 
embarrassing investigations exposing violations of labor laws or codes of conduct that might cause the brands to cancel orders. In this way, requiring apparel companies to disclose their supplier factories introduces a new risk for the factory owners as well as the apparel companies.

Part of the risk to the factory owner is that their relationship with the apparel company may make the factory vulnerable in the event of union organizing campaigns or other controversies relating to labor practices in the factories. Pressure from the apparel company to avoid labor-related controversies may de facto restrict the range of actions available to the factory owner. A simple example can expose how. Box 1 sets out the list of Canadian factories supplying Nike and Levi-Strauss, as disclosed in both company's 2005 factory disclosure lists. Another 250 odd Canadian factories are disclosed on the website of the WRC ${ }^{17}$.

Box 1: Canadian Factories Supplying Nike and Levi-Strauss, 2005

\begin{tabular}{|l||}
\hline Nike \\
Canada Bestile Apparel Inc. 841 Progress Ave., Scarborough Ontario M1h $2 \mathrm{x} 4$ \\
Canada Ce Composites Baseball 5390 Canotek Road Unit 20 Ottawa Ontario K1j $1 \mathrm{~h} 8$ \\
Canada Ironhead Originals Inc. 45 Ironside Crescent Unit 4 Toronto Ontario M1x $1 \mathrm{n} 3$ \\
Canada Kiangtex Co. Ltd 46 Hollinger Road Toronto Ontario M4b 3g5 \\
Canada Lamasz Sport Inc 435 Limestone Crescent Toronto Ontario M3j 2r1 \\
Canada Les Vêtements Sp Apparel Inc. 1237 Boulevard Industriel Granby Quebec J2j $2 \mathrm{~b} 8$ \\
Canada Mcgregor Industries Inc. 401 Wellington Street West Toronto Ontario M5v 2h7 \\
Canada Silver Spider Knitting Ltd. 212 Supertest Road Toronto Ontario M3j 2m2 \\
Canada The Athletic Sportshow Inc. 2473 Dixie Road Mississauga Ontario L4y 2al \\
Canada The Incredible Clothing Company - Dufferin 4548 Dufferin Street Toronto Ontario M3h $5 \mathrm{~s} 2$ \\
Levi-Strauss \\
Canada, Forever Garments, 1025 Westport Crescent, Mississauga, L5T 1E8 \\
Canada, H.A. Sheldon Canada Ltd., 2025 Midland Ave., Scarborough M1P 3E6 \\
Canada, Print Outfit Inc., 5435 Maingate Drive, Mississauga, L4W 1G6 \\
Canada, SDR Distribution Services, 1880 Matheson Blvd., Mississauga, L4W 5N4 \\
\hline \hline
\end{tabular}

Canadian unions, such as UNITE-HERE Canada for example, could target factories on the list for organizing campaigns. The same challenges that

17 See Worker Rights Consortium, Factory Disclosure Database, http:/www.workersrights.org/search/ (last visited Nov. 3, 2007). 
exist in every organizing campaign would still confront the Union. However, if preserving their contracts with the major brands is valuable to them, then these factory owners have a particular vulnerability that the union could exploit in their organizing campaign. The organizing union could present a letter, copied to Nike or Levi-Strauss as the case may be, advising that any illegal conduct during the campaign will result, not only in unfair labor practice charges, but also in a public campaign against the factory owner and the apparel company, and if applicable, complaints filed with the Workers Rights Consortium or the Fair Labor Association (both of which are discussed below). UNITE could advise the companies also that it is working with local (Maquila Solidarity Network in Toronto) and foreign (Clean Clothes Campaign, etc.) NGOs in the campaign, and that the company's behavior will be closely watched and misconduct publicly reported.

This is no guarantee of union organizing success of course, but factory disclosure can be used as one of many tools in the sorts of creative corporate campaigns unions are already using to battle employers. ${ }^{18}$ The same process can be used for factories in developing countries. The key lies in the ability of civil society organizations and unions to coordinate transnational networks that can track labor practices in factories, link those factories to the brand-sensitive companies that source from them, and wage successful public relations campaigns challenging those practices. Factory disclosure makes this easier, and to the extent that factory owners and apparel brands perceive a risk in these sorts of campaigns, factory disclosure may encourage some factory owners to steer clear of controversy by staying within the bounds of acceptable labor practices, as defined by laws or codes of conduct.

\section{THE ORIGINS OF FACTORY DISCLOSURE}

Factory list disclosure is not the brainchild of governments. Like so much of the contemporary governance of labor practices within the global supply chains of multinational apparel companies, factory disclosure has

${ }^{18}$ See, e.g., D. J. Doorey, Neutrality Agreements: Bargaining Association Rights in the Shadow of the State, 11 (1) Can. Lab. \& Emp. L.J. 41, 43 (2006). 
its origins in grass roots movements of private, non-state actors seeking to address perceived failures by states to protect workers. It gained prominence in the late 1990s, primarily as a result of the efforts of a group of university students in the United States.

\section{A. The United Students Against Sweatshops \& THE WORKERS' RIGHTS CONSORTIUM}

The story begins in the summer of 1997 at the New York offices of UNITE. The Union assigned several university student interns the task of investigating relationships between university apparel and labor sweatshops in the supply chains of multinational apparel companies. ${ }^{19}$ The Union was considering a campaign targeting student awareness of the exploitation of workers in the apparel industry. The interns began questioning university administrators, and they quickly learned that the universities did little to investigate how and where their branded clothing was made.

Informal campaigns soon began at universities such as North Carolina (Chapel Hill), Duke, Michigan, Wisconsin, and California, as students sought information and affirmations from administrators that university branded clothing was not being made in factories in which labor laws were violated. Initially, these inquiries focused primarily on clothing made by Nike and Reebok, two companies that were receiving negative media attention at that time for the labor practices in their overseas supplier factories. University apparel was not an insignificant market for these companies. In the late 1990s, for example, Nike alone had exclusive supplier deals with several large American universities worth in millions of dollars, and the university apparel market was worth in the billions of dollars to apparel companies. ${ }^{20}$

\footnotetext{
${ }^{19}$ L. Featherstone, Students Against Sweatshops 11 (Verso 2002).

${ }^{20}$ Id.
} 
By early 1998, a significant grassroots movement of students had emerged, motivated to challenge their university administrations on the issue of university apparel and factory conditions. In the spring of that year, students from over 30 schools converged on New York City, where they formed the United Students Against Sweatshops (USAS). These events coincided with negotiations under the Apparel Industry Partnership ("AIP"), an initiative introduced by the Clinton Government in 1997 designed to detract public criticism of the apparel industry by creating a model of private governance that would address the seemingly endless stream of reports about labor abuses in apparel factories both in the U.S. and abroad. In 1998, the AIP, bloodied by the late defection of the two union participants, announced the creation of the Fair Labor Association ("FLA"), an organization that would monitor factories and encourage best practices within the apparel industry.

From its outset, the USAS perceived itself, and was perceived by industry, as an alternative to the FLA model. Few companies welcomed this development. The FLA and its supporters aggressively attempted to coopt the movement and the university administrations. ${ }^{21}$ One concern most apparel corporations shared was USAS's focus on disclosure and transparency, which was apparent from its inception. During their 1997 summer internship at UNITE, the students had reviewed existing codes of conduct promulgated by apparel companies. Tico Almeida, one of those students, explains how this led USAS's early leaders to focus on transparency, including factory disclosure:

...we noticed that not a single company included a provision for public disclosure of factory locations or independent monitoring reports. The conclusion was obvious: if we were to hold the manufacturers of our college merchandise accountable, we were going to have to force them to open themselves to public scrutiny. $^{22}$

\footnotetext{
${ }^{21}$ Id. at 13. At one point, according to Featherstone, Clinton's Chief Economic Advisor, Gene Sperling, promised monthly meetings with USAS if they supported the FLA

${ }^{22}$ Id. at 16.
} 
At that time, voluntary public disclosure of the identity of global supply chain factories was virtually unheard of in the apparel industry. Certainly, none of the major apparel companies were doing this, and for most, the idea had probably never been seriously considered.

That began to change in January 1999, when students at Duke University engaged a sit-in at the University administration's offices demanding, and ultimately obtaining, an agreement by the University to disclose a list of every factory that produced apparel for the university. This victory spawned similar campaigns at other schools, including Georgetown, Arizona, Wisconsin, North Carolina (Chapel Hill), and Michigan. The students believed that factory disclosure would enable linkages between the students, labor organizations, and the workers in the factories that could facilitate information sharing about labor practices in the factories where university apparel was produced.

In July 1999, buoyed with confidence from these victories, the students met in Washington to plan a way forward. The students agreed to continue to push for full factory disclosure as key objective. They decided to develop a new organization to help manage the growing database of global apparel factories, and to develop a structure for monitoring and reporting on conditions of work in those factories that could challenge the FLA model. The new FLA code required limited independent monitoring of supplier factories, but required neither public disclosure of factory lists nor disclosure of the monitors' reports. The new organization was named the Workers' Rights Consortium (WRC). It held its founding convention in April 2000.

The approach of the WRC was distinct from that of the FLA in a number of important ways. For one thing, it did not include industry representation on its governing board, thereby permitting it to claim independence from the industry it sought to monitor. Its governing board consisted of representatives from university administrations, unions, students, and academics. It did not accredit factories or monitors, because of the belief that short of a full investigation, it was not possible for a monitoring organization or a sourcing corporation to know what conditions of work were during any particular production run. The WRC requires schools to adopt a code of conduct (of their choice, but the WRC also offers a model code) that they will then impose on their supplier 
factories. The model permits workers or organizations to file complaints alleging breaches of corporate codes of conduct. Those complaints are then investigated and reports are prepared and published on-line. ${ }^{23}$

As noted, schools that affiliate with the WRC-and there are now over 150 of them - must obtain from their suppliers a list of all of the factories used in the production of the university clothing. The WRC compiles that list of factories and posts it on the organization's website in a format that permits searches by factory, university, country of factory, and licensee name. For example, when we search "Canada", we are given about 250 Canadian factories that supply clothing to Canadian and American universities that are signatories to the WRC. If we then link to one of those factories, we find the name of company, the street address of factory, and a contact person with their contact information. We can also link to the particular schools for which the factory is a supplier. The same information is available for every factory in the database, worldwide.

The apparel companies that supplied schools affiliated with the WRC found themselves faced with a new conundrum: publicly disclose their factory list, or risk losing their university apparel contracts. Some companies did not initially respond favorably to this demand, including Nike, as discussed in Part III A. Other companies frankly admitted that they did not know what factories supplied their products because they used sourcing agents and intermediaries. This position further supported the student's argument that the multinational apparel companies were unaccountable for the conditions of work in their supplier factories.

Nevertheless, by the late 1990's support for factory disclosure was gaining momentum in the U.S., within university administrations and student bodies, and now also among labor rights groups. For example, in 1999, an NGO called the National Labor Committee (NLC), in coordination with a religious-based human rights organization, People of Faith Network,

\footnotetext{
${ }^{23}$ See, e.g., Worker Rights Consortium, Assessment Re Gildan Activewear El Progeso (Honduras): Findings, Recommendations and Status Report (July 29, 2004) http://www.workersrights.org/Freports/Gildan-El_Progreso_7-29-04.pdf (re. factories supplying Montreal-based Gildan Activewear),
} 
initiated a campaign they called "People's Right to Know", which called upon American companies to publicly disclose their factory lists. ${ }^{24}$ More importantly, since many universities were accepting the demands of the USAS movement for factory disclosure, by 1999 , many apparel companies supplying those universities had begun to disclose their factory lists.

For those companies that relied heavily on the university apparel market, the loss of business that would be associated with walking away from that market probably made the decision a relatively easy one. At Gear for Sports, for example, the university/college market comprised $\$ 40$ million dollars in annual sales, or about 20 percent of its total sales. ${ }^{25}$ It quickly accepted the requirement to disclose the factories supplying universities affiliated with the WRC, and in February 2000, it began publishing its factory database on its website, making it one the first American companies to do so, a point it then emphasized on its corporate website as evidence of its commitment to social responsibility. ${ }^{26}$

Many other companies also agreed to disclose their factories in order to preserve their university markets. By October 1999, several months before the WRC held its founding convention, even Nike had conceded that the cost of losing the university market outweighed its objection to the USAS model and factory disclosure. Nike reluctantly now had its first taste of public factory disclosure, as did many other apparel corporations, thanks to the USAS movement. ${ }^{27}$

${ }^{24}$ The NLC was lead by Charlie Kernaghan, who had famously "made Kathie Lee Gifford cry" in 1996, when he publicly announced that goods for the television personality's personal line of clothing were made by Honduran children working long hours in dangerous conditions.

25 Press Release, GEAR For Sports, Collegiate Sportswear Manufacturer Gear For Sports To Disclose Factory List (October 27, 1999), http://www.gearnosweat.com/oct99.html.

${ }^{26}$ Id. Jansport, a maker of backpacks and apparel, began publishing its supplier factories at around the same time, however, it has since removed the list from its website. I have attempted to contact the company by e-mail and phone to obtain an explanation for this, but I have yet to receive a response.

${ }^{27}$ Its opposition to the WRC did not diminish, however, particularly that of its CEO, Phil Knight, who expressed his opposition dramatically in 2000 by withdrawing a large donation to the University of Oregon when the school joined the WRC rather than the 


\section{B. INDUSTRY SLOWLY COMES ON BOARD}

The USAS/WRC movement deserves credit for planting the seeds of factory disclosure, but the idea soon spread beyond university campuses and began to gain credibility within industry. Companies that had decided to disclose their factories in order to preserve contracts with university customers realized quickly that they could use this disclosure to bolster their public image. I noted earlier how Gear for Sports linked its decision to disclose its university apparel factories to its self-professed philosophy of corporate social responsibility. Even Phil Knight of Nike, who had battled fiercely against the USAS movement and WRC, was not above bragging that Nike's 1999 agreement to disclose the factories supplying its university customers was evidence of its commitment to improving labor practices in its supplier factories. ${ }^{28}$

Factory disclosure had begun a slow ascent as a new badge of honor within the apparel industry. Corporations were taking possession of the idea, and were using it as evidence that they "had nothing to hide" from the public. ${ }^{29}$ In a 2003 op-ed piece in the British Guardian newspaper, the Founder and Former CEO of The Body Shop argued that factory disclosure was a crucial "first step" towards eradicating labor abuses around the world:

Corporations continue to hide the factories they use around the world to make the goods we purchase. Wal-Mart, for example, uses 4400 factories in one Chinese province alone. As a first step,

FLA. See Phil Knight, Comment, Statement from Nike founder and CEO Philip H. Knight regarding the University of Oregon, Oregon Daily Emerald, Apr. 24 2000, at news, available

at: http://media.www.dailyemerald.com/media/storage/paper859/news/2000/04/24/News/Sta tement.From.Nike.Founder.And.Ceo.Philip.H.Knight,Regarding.The.University.Of1963996.shtml.

${ }^{28}$ See Phil Knight's opinion piece in The Oregon Emerald, id. (in his list of actions Nike had taken to address labor issues, he included: "Disclosed the U.S. and global locations of the 45 factories that produce collegiate licensed apparel.").

${ }^{29}$ See, e.g., id. 
we need full public disclosure of all factory names and locations. Such transparency will make it much harder to hide abuses... ${ }^{30}$

Even the apparel industry newsletter, Juststyle, hopped on the factory disclosure bandwagon when in a 2003 editorial it lamented the FLA's annual report for its failure to disclose factory addresses. ${ }^{31}$

The USAW/WRC model had another important effect. It created a controlled experiment for the companies by allowing them to disclose a segment of their factories in a context in which many of their competitors were doing likewise. Some companies learned that a proactive response that included dialogue with NGOs and the WRC upon learning of a problem in a factory tended to be rewarded by muted criticisms and occasionally even praise. This realization that "engagement" with the labor activist community could sometimes be more beneficial than confrontation and denial, was not a phenomenon exclusive to the WRC participants - it is a common theme found in the comments and company literature of major brand-based companies by the late 1990s. But the WRC factory disclosure experiment deserves credit for causing at least some companies to realize that disclosing their factory list did not cause the sorts of problems they might have previously anticipated.

\section{2005: The Year of Voluntary Disclosure of CoMPlete FACTORY LISTS}

It is this context that we need to interpret the unlikely events of 2005. In April 2005, Nike surprised everyone by suddenly releasing its global factory database, at that time, amounting to nearly 750 factories worldwide. Other major apparel and footwear companies soon followed: Levi-Strauss, Timberland, Puma, Adidas, and Reebok. The decision to

\footnotetext{
${ }^{30}$ A. Roddick, The Price of Dignity, The Guardian, Sept. 22 2003. My thanks to ETAG for referring me to this article, and to the article referred to in the next note.

${ }^{31}$ L. Barrie, Editorial, Juststyle, June 12, 2003 ("If there are any flaws in the report then the main one must be that the names and the locations of the factories surveyed have not been disclosed.... [S]urely releasing such information would increase pressure on the factories to comply.").
} 
release complete lists of factory addresses by corporate giants like Nike and Levi's appeared to instantly and fatally undermine the two most common industry arguments against factory disclosure. The first argument is that it is not possible for companies with complex global supply chains to track and record a factory database. Nike and Levi's utilize hundreds of factories dispersed around the globe, yet both were able pull together their factory list and publish it in quick order. Maintaining a factory list is not impossible, it is rather an issue of business model and will power.

The second argument is that factory location is proprietary intellectual property and that publicizing it would seriously harm the competitiveness of the apparel companies. This argument loses steam with each new company that discloses its factory list. If this information is so valuable, why are leading apparel companies prepared to give the information away for free? Factory disclosure proponents have always challenged the argument that factory lists are a form of "trade secret", pointing out that apparel industry insiders know which factories are supplying which companies, or can easily find out.

Michael Kobori, LS's Vice President, Corporate Code of Conduct supports this assessment:

... its not really proprietary because we share these suppliers with most of the other brands anyway. We're in the same factories as Gap ... so they already know what we're sourcing... [In] all of our localities, local NGOs know exactly where Levi's is, where GAP is, where Nike is. ... [The] other piece of information you look at is there's movement in the industry. I mean people within our sourcing organization don't stay forever, they go over to competitors, and competitors' people come over here.

Patrick Neyts, who led LS's Code of Conduct Department before Kobori and supported the idea of making voluntary factory disclosure, once responded to the expression of concern within the organization that factory disclosure would undermine the company's competitive advantage by compiling a list of one of LS's competitor's supplier factories. His point in doing so was to demonstrate to LS executives that industry insiders can 
quickly find out which factories competitors use if this were somehow valuable information. ${ }^{32}$

Moreover, even companies that have been unwilling to publicly produce their factory lists have offered to share this information with their competitors. For example, in 2004, the Hudson's Bay Company (HBC) began pushing for an industry database through which competitors could share information about factories and collaborate on monitoring. ${ }^{33}$ Later that year, $\mathrm{HBC}$ joined with several other companies and industry organizations to form the Fair Factories Clearinghouse, an initiative that permits apparel companies to share information about their factories, without that information being made publicly available. ${ }^{34}$ These developments suggest that it is not competitors from which apparel companies seek to hide their factories, but the various antagonistic actors that may wish to use the information to help organize the workers, or to expose the conditions in those factories to the outside world.

The flurry of companies disclosing their global factory lists in 2005 did not immediately trickle across the border to Canada. In the summer of 2005, the Federal Government announced in a brief press release that it would not pursue ETAG's proposal for mandatory factory disclosure. ${ }^{35}$ It referred to the Report it had commissioned from the Conference Board of Canada, released earlier that year. That Report rejects factory disclosure primarily on the basis that: (1) industry was strongly opposed to disclosing its intellectual property to competitors; (2) the proposal would be

32 Interview with Patrick Neyts, Toronto, 2007. Kobori agreed with this assessment, noting in a 2006 interview: "If our competitors want to know where we're sourcing, its not that hard to find out because the suppliers talk. The supplier will tell us who else is sourcing with them. We ask them, and they tell us. There's no qualms about sharing that information.

${ }^{33}$ See M. Strauss, HBC Executive Leads Drive to Stem Sweatshop Labor, Globe and Mail, May 192004 at B1.

${ }^{34}$ See, Fair Factories Clearinghouse, http://www.fairfactories.org/index.htm (last visited Nov. 3 2007).

${ }^{35}$ See Press Release, Industry Canada, Industry Canada/Minister Emerson Releases Public Policy Forum Report on ETAG Proposal (July 22, 2005), http://www.marketwire.com/mw/release.do?id=549503. 
technically difficult to implement; and (3) factory disclosure did not provide consumers with useful information in any event. ${ }^{36}$

However, there are now cracks in the united front of the Canadian apparel industry. Mountain Equipment Co-op (MEC), a producer and retailer of outdoor sports apparel and equipment will disclose its complete factory list beginning in 2008. According to Harvey Chan, MEC's Director of Ethical Sourcing, the decisions to create his position and to hire him, and ultimately to disclose the factory list, were the direct result of a campaign by the Maquila Solidarity Network, which in 2001 "awarded" MEC with the mock "Fence-sitter of the Year" award. ${ }^{37}$ MSN criticized MEC for seeking to present itself as an ethical company while refusing to take a clear and firm position supporting freedom of association rights and bans on child labor and for remaining secretive about its factory monitoring practices.

In announcing its decision, MEC noted that transparency is now expected of responsible corporations, and that factory disclosure will encourage additional factory monitoring by "third parties":

...transparency has become more important than protecting our resources. We can't foresee to what extent we'll put our business at risk by disclosing factory locations, but we agree that the information should be made public. We hope that our disclosure will inspire collective action and encourage third parties to visit factories and verify conditions. ${ }^{38}$

\footnotetext{
${ }^{36}$ The Conference Board of Canada, Study of A Proposal (and its alternatives) to Amend the Textile Labelling and Advertising Regulations: Applying the Conference Board's Optimal Policy Mix Framework (Feb 2003) http://strategis.ic.gc.ca/SSI/ct/ct02546e.pdf. I have argued elsewhere that the Report underestimates the potential impact factory disclosure could have on the internal management systems with the apparel corporations. See D.J. Doorey, Disclosure of Factory Locations in Global Supply Chains: A Canadian Proposal to Improve Global Labor Practices, 55 Can. Rev. Soc. Pol'y 104 (2005).

${ }^{37}$ Interview with Harvey Chan, Director of Ethical Sourcing, MEC, Toronto, 2007.

38 MEC, Can't You Tell Us Which Factories Make Your Gear?, http://www.mec.ca/Main/content_text.jsp?FOLDER\%3C\%3Efolder id=2534374302883 $567 \&$ bmUID $=1179328056110$, (last visited Nov. 3, 2007).
} 
Other Canadian companies will be under pressure to follow, as factory disclosure becomes more entrenched as a norm of corporate social responsibility.

\section{FACTORY DISCLOSURE AT NIKE AND LEVI- STRAUSS (LS)}

The decision of companies like Nike and LS to disclose their factory lists contrasts so sharply with the general industry practice, particularly in Canada, that it is intriguing to examine how the decision to disclose was made. More importantly, by examining how these companies prepared for the risks associated with the disclosure may provide some insight into the following key question: How would companies respond if they were required to disclose their supplier factory lists?

True, we cannot assume that all companies will prepare for regulated factory disclosure in the ways that LS and Nike prepared for voluntary regulation. Nevertheless, by observing the measures that these companies took to become comfortable with factory transparency, we learn how large, sophisticated apparel corporations manage risk, and this knowledge is useful in assessing what sorts of responses factory disclosure regulation might provoke in other companies.

\section{A. Understanding NiKE's DeCision to Disclose its Global FACTORY LIST}

In a now famous speech to the National Press Club in the spring of 1998, Phil Knight, CEO of Nike conceded that "the Nike product has become synonymous with slave wages, forced overtime, and arbitrary abuse".39 $\mathrm{He}$ was using the speech to introduce new initiatives that Nike hoped

\footnotetext{
${ }^{39}$ J. Cushman, Nike Pledges to End Child Labor and Increase Safety, New York Times, May 13, 1998, International Business
} 
would stall the onslaught of negative publicity the company had endured over the past decade for the conditions of work in their global supplier factories. Knight told the audience that consumers do "not want to buy products made in abusive conditions."

Those words reflected an important transformation at Nike that occurred during the 1990s. Nike's business model has, since its earliest days in the 1970 s, been based on global outsourcing to low cost jurisdictions-first to Japanese contractors, then in the 1980 s to Korea, Thailand, China, and Taiwan, and later to Indonesian and Vietnam. It has used its own production facilities at various times in its history, but this is the exception to the general rule that Nike is a design and marketing company. Production is outsourced to hundreds of contractor factories dispersed globally.

For decades, Nike's position on its responsibility for labor conditions in its contractor's factories was that it had no responsibility. John Woodman, a senior Nike employee in Indonesian expressed this sentiment in 1991, when he told a reporter that it was "not within our scope to investigate" conditions of work in contractor factories. ${ }^{40}$ This was a common attitude, not only at Nike, but within industry generally. In the 1990s, however, the interests of various private actors-labor activists, unions, human rights and religious NGOs, and investigative journalists-converged on the unlikely subject of factory conditions within the supply chains of global corporations. Nike, perhaps more so than any other company, became the target of these campaigns.

Media images of children sewing Nike soccer balls and running shoes juxtaposed against the millions of dollars Nike paid sports celebrities to market their products proved an effective formula for a new generation of social activists who exploited the internet in a global anti-Nike campaign. ${ }^{41}$ Nike's traditional line denying responsibility for conditions in

${ }^{40}$ R. Barnet \& J. Cavanagh, Global Dreams: Imperial Corporations and the New World Order (Simon and Schuster, 1994). See also D. Katz, Just Do It: The Nike Spirit in the Corporate World (Random House, 1994) (quoting a Nike official: "We don't pay anyone in the factories, and we don't set policy within the factory: it is their business to run.")

${ }^{41}$ Some of the campaigns targeting Nike are reviewed in D. Murphy \& D. Mathew, Nike and Global Labor Practices (unpublished paper, Jan. 2001) (on file with author) and R. 
contractor factories quickly proved untenable to a growing number of skeptical shoppers. Nike's Vice President of Labor Compliance during the mid-1990s reflected on the company's early reactions to the corporate campaigns as follows:

Nike made a real mistake. I think we reacted negatively to the criticism. We said, wait a minute, we've got the best corporate values in the world, so why aren't you yelling at the other folks. That was a stupid thing to do and didn't get us anywhere. If anything it raised the volume louder. ${ }^{42}$

A new strategy was needed to deflect the growing criticism, which by the early 1990's, Nike executives began to perceive as a threat to their brand image.

\section{LABOR COMPLIANCE \& THE MANAgEMENT OF SUPPLy CHAin Risk}

a. The Nike Code of Conduct

Nike's first reaction was to treat the growing public criticism as a public relations and communications problem. In 1991, the company hired Dusty Kidd, a journalist, to be its new PR Director. One of the first things Kidd did, working with senior representatives from Production, Communications, and Legal, was draft a new code of conduct for Nike. Nike's Code of Conduct was released in 1992 and was modeled loosely on Levi Strauss's Guidelines, which had been released earlier that year. ${ }^{43}$ The new Code committed Nike publicly to accepting at least some

Locke, The Promise and Perils of Globalization: The Case of Nike (unpublished paper) (on file with author).

${ }^{42}$ David F. Murphy, David Mathew, Nike and Global Labor Practices: A case study prepared for the New Academy of Business Innovation Network for Socially Responsible Business (unpublished paper, January 2001) http://www.newacademy.ac.uk/publications/keypublications/documents/nikereport.pdf, at 7 (quoting Dusty Kidd, PR Director, Nike).

${ }^{43}$ Id. 
responsibility for what happens in its supplier factories. ${ }^{44}$ The Code described a set of labor standards that it expected its contractors to apply, but it did not describe precisely how compliance would be monitored, nor did it include any commitment by Nike to disclose what factories it used or information about the results of monitoring.

The Code was initially implemented by the Production Departments within the different business units (Apparel, Footwear). However, the Production personnel were neither trained as labor experts nor especially focused on the Code's implementation. ${ }^{45}$ The Code was distributed to factory owners, with an instruction to sign the document, to comply with it, to post it in the factory, and to report to Nike on its compliance biannually. However, Nike did not initially monitor compliance in any systematic way.

By 1996, Nike had decided that the introduction of their Code had so far won them little public goodwill. That year, it introduced a new Labor Practices Department, and assigned Dusty Kidd to lead it. The new Department would assume the primary function of implementing and monitoring the Code. Nike also decided to use external auditors to monitor compliance with its Code. It first used the accounting firm Ernst \& Young. However, after a scathing report by Dara O'Rourke, who described how the firm sent inexperienced auditors who failed to notice or report clear violations of local laws and the Nike Code ${ }^{46}$, Nike switched to Price Waterhouse Cooper (PWC). It instructed PWC to develop a user's manual for monitoring compliance in its global factories. ${ }^{47}$

Nike's SHAPE internal monitoring system was introduced in 1997. The SHAPE audit was general in nature and intended to provide the company with a quick survey of the general conditions of a factory. Its purpose

\footnotetext{
${ }^{44}$ The Code of Conduct is available on-line at:

http://www.nike.com/nikebiz/nikebiz.jhtml?page=25\&cat=code\#code

${ }^{45}$ Murphy, supra note 42 , at 6 .

${ }^{46}$ D. O'Rourke, Smoke from a Hired Gun: A Critique of Nike's Labor and Environmental Auditing in Vietnam as Performed by Ernst and Young (1997) http://nature.berkeley.edu/orourke/PDF/smoke.pdf.

${ }^{47}$ Murphy, supra note 42 , at 6 .
} 
was to provide Nike with an initial assessment of whether the factory was at least in the ballpark in terms of a potential supplier that could satisfy the Code of Conduct. While the SHAPE audit was therefore not a good indication of whether the Code was actually being complied with on a daily basis, it did have the benefit of introducing a formalized system in which Nike personnel were required to open a SHAPE file for each factory. In other words, it facilitated an important new record keeping process at Nike specifically related to labor compliance.

\section{b. The Global Factory Database}

In 1998, Nike created a Corporate Responsibility and Compliance Division ("CRD"), and it named Maria Eitel as the first CRD VicePresident. CRD houses several Departments, including Compliance (headed by Dusty Kidd) and Considered, which is intended to facilitate the integration of corporate responsibility issues throughout the business by bringing together sustainability and compliance people working within the various Nike product groups. Considered reports to the VP of CRD, but also to the heads of the product lines (Apparel, Footwear) as a means of coordinating compliance issues. When the CRD was initially created, it reported directly to Communications, suggesting that corporate responsibility issues remained principally a concern of public relations. That reporting relationship ended around 2004, and now CRD reports directly to the CEO.

Within the Compliance Department, there are four Field Managers assigned to Nike's regions: the Americas, South Asia (Thailand, Indonesia, Bangladesh, India, Sri Lanka, Malaysia) North Asia (China, Vietnam, Cambodia, Taiwan, Korea), and EMEA (Europe, Middle East, and Africa). These Managers are responsible for monitoring the day to day oversight of factory compliance with labor laws and the Nike Code of Conduct, as well local stakeholder engagements. The Field Managers work in offices within their regions, and have assigned to them Compliance Field Staff. There are today approximately 75 full-time employees working in Compliance, about 50 of whom are Field Staff, whose job it is to visit the supplier factories, conduct audits, and enter their reports into Nike's global factory database. 
That database was created in the early 2000's to help Nike's Head Office track its global supply chain and to enable access to the various SHAPE and other audits being conducted in the field. The various Sourcing offices had kept their own production databases for some time to track order information like delivery times, quality, and other specifications. However, about five years ago, a model was developed that would allow the Compliance Department to access information regarding labor practices at each supplier factory, as explained by Caitlin Morris:

What makes Compliance unique is that we're the only place currently in the company that has visibility to everybody's individual sourcing database, and the way we use it is, when a factory enters the system, once the factory has been approved in the [New Source Approval Process], and compliance is the last step in that, it gets a file created in our database. The second thing that happens is all the auditors in the field are uploading data information about the factories into the database. So when I run a report, I can see when the factory was last visited by an auditor, what the findings were, what did they resolve, what was our discussion with the business unit about unresolved factory issues, and so its kind of a running table.

The content of the information in the database has been improved by the introduction of additional internal audit systems at Nike, which complement the more general SHAPE audits and the occasional external audits conducted under the auspices of the FLA or even the WRC.

In 2003, Nike began using a multi-step factory compliance model they named the "New Source Approval Process". Every factory must still pass a basic SHAPE inspection, but approximately 25-33 percent of Nike factories also now undergo a more comprehensive "M-Audit". The MAudit has been conducted by internal Nike Compliance staff since Nike terminated its relationship with PWC several years ago. ${ }^{48}$ Nike performs a

\footnotetext{
${ }^{48}$ Nike stopped using Price Waterhouse Cooper in 2002. PWC had been highly criticized for its foray into labor monitoring, most notably in a 2000 report prepared again by O'Rourke, who after accompanying PWC auditors to factories supplying Nike and other companies described how the auditors simply ignored or missed serious labor problems in the factories. See D. O'Rourke, Monitoring the Monitors: A Critique of PWC Labor Monitoring (2000), http://nature.berkeley.edu/orourke/PDF/pwc.pdf.
} 
"risk assessment" on its supplier factories, and focuses its auditing resources on factories found to be in relatively high risk of noncompliance. $^{49}$ Factories are ranked between $\mathrm{A}$ and $\mathrm{D}$, with $\mathrm{D}$ being the highest risk. Factories that fail either a SHAPE, or a M-Audit inspection are either not approved, or are permitted an opportunity to implement a Master Action Plan, which will set out what the factory needs to do to be accepted as a Nike contractor.

In practice, since each factory, and indeed each issue, is assigned a risk ranking ( $\mathrm{A}$ to $\mathrm{D})$, Compliance officials in the Beaverton headquarters focus on high risk factories and issues ("D-Rated"), while audits of low risk factories will occur less frequently. With respect to D-Rated issues and factories, senior Head Office Compliance personnel meet monthly with Nike Apparel representatives to discuss the status of remediation efforts and whether to reclassify the factory or terminate the relationship if improvements are not being made.

Thus, Head Office in Oregon can now view the status of any factory in the world as of the most recent audit. Discussions between Compliance and Sourcing will also occur on an ad hoc basis as issues arise. Compliance and Sourcing personnel share regional offices, so they are physically in the same space. When Compliance Field Staff discover labor compliance problems in a factory, they will report this to the Sourcing agent with responsibility over the factory, and the information may be entered into the factory database, where it can be accessed by senior Compliance staff. Sometimes labor practice problems are brought to the attention of Nike by NGOs. In that case, a compliance officer in the region will be sent to investigate and will then report to the Regional Compliance Field Manager. If a problem is confirmed, a plan of action will be discussed locally by the Sourcing team and the Compliance Field Manager, and the information will be passed on to the Director of Labor Compliance, and then, depending upon the seriousness of the matter, to Hannah Jones, VP $\mathrm{CRD}$, to the Legal Department, and the heads of business units to discuss.

${ }^{49}$ The factors considered in the risk assessment are listed no Nike's website. They include the country and region, past history of compliance, nature of work and size of the workforce. 
In relation to very serious issues, such as a death of a worker in one its supplier factories, the information would be conveyed up the ladder very quickly, probably within a day. ${ }^{50}$

\section{The Move Towards FaCtory Disclosure at NiKe}

\section{a. Nike and External Engagement}

Nike's participation in the 1997-98 AIP process, and its subsequent involvement with the Fair Labor Association forced Nike to engage in ongoing dialogue with external stakeholders and NGOs, something Nike had not actively pursued in the past. Its gradual movement towards greater engagement with external actors was influenced by the hiring of Maria Eitel, who became Nike's first CRD Vice President in 1998, and its point person on the FLA participation. Like Hannah Jones, her successor in this position, Eitel had worked previously in community affairs at Microsoft. Eitel was more open to engaging with Nike's critics than previous Nike executives, and the AIP was an important early opportunity for her to tentatively reach out to NGOs and even unions. ${ }^{51}$ Unfortunately for Nike, the unions involved with the AIP withdrew, with the effect that the newly created FLA lacked credibility amongst many of Nike's critics, including the burgeoning student movement.

Nike, and its CEO Phil Knight, assumed the point position in a very public campaign to persuade universities to support the FLA rather than the USAS model and the WRC. Nike walked away from lucrative supplier contracts with Brown University and Michigan when those schools announced their intention to support the USAS rather than the FLA. To be fair, Nike's objection to the USAS and the WRC was not limited to factory disclosure and transparency; the absence of industry representation was probably Nike's major concern, along with the complaint-based investigation model of the WRC, which Nike characterized as a "gotcha" process aimed at embarrassing apparel companies. Indeed, in March 1999, Nike made a surprise offer to 34 of its university business partners to disclose its factories supplying university apparel, but only in the unlikely

\footnotetext{
${ }^{50}$ Interview with Caitlin Morris.

${ }^{51}$ Ibid.
} 
event that all of its competitors did the same, and on condition that the universities join the FLA. ${ }^{52}$

In truth, Nike's initial reaction to the idea of public factory disclosure was, like that of most other apparel companies, hostile. It adopted the common mantra of the apparel industry at the time: that this information was proprietary intellectual property and that disclosing it would mean handing over to its competitors a crucial strategic business advantage. ${ }^{53}$ Nike had other concerns at the time too that discouraged company officials to speak publicly about conditions in their supplier factories. In 1998, it was sued by Marc Kasky for making false claims in its advertising materials about the treatment of workers in its supplier factories. ${ }^{54}$ That lawsuit lingered over the company until 2003, when it was settled out of court on grounds that included a relatively meagre payment of $\$ 1.5$ million dollars to the FLA.

Nevertheless, in October 1999, Nike disclosed the 41 factories (in 11 countries) used in university apparel production to avoid losing its share of the university apparel market, then constituting approximately 1 percent of its total business and nearly 10 percent of its total factory supplier list. Critics challenged Nike to go further, and to disclose its entire factory list, but the company refused, arguing that: "We're definitely giving our competitors an advantage with this, but we figured it was appropriate for the intellectual property at stake, so we're still taking the position that there's important business reasons why we don't want to disclose the factory list." ${ }^{, 55}$ Nike perceived the disclosure as a necessary risk to

52 J. Manning, Nike Treads on a Limb With a Promise of Disclosure, The Oregon, Mar. 121999 (Ebenshade has noted that Nike's proposal was perceived cynically by the student activists; "as a bride to bring the university code movement into a forum Nike could to some extent control.")

${ }^{53}$ M. Gillen, The Apparel Industry Partnership's Free Labor Association: A Solution to the Overseas Sweatshop Problem or the Emperor's New Clothes?, 32 N.Y.U. J. Int'1 L. \& Pol. 1059, 1097, note 138 (2000).

${ }^{54}$ For discussion of this case, see W. Eldridge, Just Do It: Kasky V. Nike, Inc. Illustrates That It Is Time To Abandon The Commercial Speech Doctrine, 12 Geo. Mason L. R. $179,(2003)$.

${ }^{55}$ Nike Website, 2000 FAQ. The link was not active when checked again in November 2007. Original content on file with author. 
maintain a small but important market, but the risk was somewhat offset by the fact that the company had already been treating the factories supplying the university market as relatively high risk, so that proportionately more attention had been paid to those factories than to the database as a whole. ${ }^{56}$

Thus, by the turn of the century, Nike had disclosed a portion of its factory list, and had agreed to a limited number of external, independent audits of its factories by way of its participation in the FLA and the WRC model. This very subtle shift towards transparency and external engagement carried over into the new millennium. In July 2000, Nike became one of the first corporations to support the United Nation's Global Compact, an initiative that asks companies to report on their efforts to ensure compliance in their factories with a set of core labor standards.

That same summer, Nike introduced an initiative called "Transparency 101 ", through which it announced it would begin posting on its website the results of audits done by PWC of some of its factories (although without identifying particular factories). Vada Manager, Nike's Director of Global Issues at that time explained:

We needed a defence against investigations into our factories from outside forces. It's a way to pre-empt nongovernmental organizations and the media from playing 'gotcha.' For us, that level of transparency was necessary and appropriate to send the message that we have nothing to hide. ${ }^{57}$

In November 2000, Nike joined CERES, an environmental sustainability NGO that calls on companies to engage external stakeholders on environmental issues and to publicly report, using the Global Reporting Initiative, on environmental issues. ${ }^{58}$

\footnotetext{
${ }^{56}$ Interview with Caitlin Morris.

57 S. Van Yoder, Beware the Coming Corporate Backlash 250 (5) Industry Week 38 (2001) (quoting Vada Manager, Director of Global Issues, Nike).

58 See CERES, Sustainable Reporting, http:/www.ceres.org/sustreporting/ (last visited Nov. 3, 2007).
} 
Thus, the rhetoric of transparency and stakeholder engagement was ubiquitous at Nike in 2000. The following year, Nike introduced a Corporate Responsibility Committee on its Executive Board which was assigned the role of overseeing the company's social performance in areas such as labor, the environment, and charitable endeavours. Also in 2001, it released its first Corporate Social Responsibility Report ${ }^{59}$, which included information about the number of factories it used in each country, the number of employees per country, average wages, again by country, and other information set out in general terms on national basis. In April 2002, the FLA announced new public reporting requirements. It would henceforth disclose information from its audits that would identify the member company that sources from the audited factory, the country in which the factory is located, the size of the workforce, the date of the audit, the name of the auditor, summaries of areas of compliance and noncompliance, and summaries of remediation plans. ${ }^{60}$ While this new model still did not disclose the specific factory the audit report refers to, it would produce sufficient information for knowledgeable labor organizations to identify this information in many cases. ${ }^{61}$

In June 2003, Nike became the first company to sign the legally binding "Sports and Corporate Wear Ethical Clothing Deed" requiring it to disclose to the Textile, Clothing, and Footwear Union of Australia the suppliers it uses in Australia and the price Nike pays for the items made by those suppliers. ${ }^{62}$ The Deed also grants the union the right to review the suppliers' books, permitting the Union to confirm that the national arbitration award is being properly implemented.

\footnotetext{
${ }^{59}$ Available on-line at: http://www.nike.com/nikebiz/nikebiz.jhtml?page=29\&item=fy01

${ }^{60}$ See Maquila Solidarity Network, Memo: Codes Update, No 10 (April 2002), http://www.maquilasolidarity.org/sites/maquilasolidarity.org/files/codesmemo 10 0.PDF.

${ }^{61}$ Interview with Bob Jeffcott, Maquila Solidarity Network, Toronto, 2006.

${ }^{62}$ See Press Release, Nike and the Textile, Clothing and Footwear Union of Australia, Nike and TCFUA Sign Ethical Clothing Deed (June 25, 2003), http://www.cleanclothes.org/companies/nike03-08-15.htm. Only about 400 workers were making Nike products in Australia at the time.
} 
Therefore, with factory disclosure under the WRC, the new reporting requirements under the FLA and the Australian Deed, voluntary reporting under Transparency 101, and the many ongoing independent investigations of Nike supplier factories by NGO's, Nike's supposed secret global factory list was becoming less of a secret everyday. Nike also continued to expand its efforts to engage with external stakeholders. In 2003, it introduces a new position within Labor Compliance, Director of Integration and Collaboration, and it moved Caitlin Morris from the Communications Division into this position. A central function of Morris' new job was to engage and collaborate with various external stakeholders, including NGOs and competitors in issues relating to labor compliance.

\section{B. The Decision to Disclose THE COMPLETE FACTORY LIST}

Then, in a move that would ultimately push Nike towards full factory disclosure, Nike invited a panel of external experts to review a draft of its 2004 Corporate Responsibility Report. The group, known formally as the Nike Report Review Committee ("Review Committee"), included Neil Kearney, the General Secretary of the International Textile, Garment and Leather Workers Federation and one of Nike's harshest critics. ${ }^{63}$ The Review Committee was asked to comment on: (1) Materiality (does the information in the report address those issues of most concern to Nike external stakeholders); (2) Completeness (does the report display that Nike has a complete understanding of the impacts of its activities); and (3) Responsiveness (does the report indicate that Nike is listening to and responding to stakeholder concerns). ${ }^{64}$ It met in September 2004 (in Boston) and again in February 2005 (in London) to review drafts of the Nike CR 2004 Report, and then presented Nike with a list of suggestions and recommendations.

\footnotetext{
${ }^{63}$ For a list of the Committee members, see Nike, Corporate Responsibility Report (2004), http://www.nike.com/nikebiz/gc/r/fy04/docs/FY04_Nike_CR_report_full.pdf at 14.

${ }^{64}$ Id., at 14.
} 
Neil Kearney strongly advocated for one of the recommendations. He believed that Nike would not receive the kind of credit it craved from the NGO community unless it released the names and addresses of its entire factory database. ${ }^{65}$ The Review Committee's recommendations, including factory disclosure, were presented by Hannah Jones, who had replaced Eitel as VP CRD in 2004, to Phil Knight and other Nike executives in the early months of 2005 . The executives sent it back to the Corporate Responsibility Division with instructions to consider a "landscape analysis", an assessment of the potential costs and benefits of full factory disclosure.

The perceived risks were easy enough to identify. There were concerns within the business that factory disclosure would facilitate a wave of NGO activism and media coverage targeting Nike supplier factories for investigation, and that unions would target the factories for organizing campaigns. There was also a concern within some parts of the organization that competitors could use the information to the disadvantage of Nike, perhaps by moving into the Nike factories and thereby eroding the factory's capacity to supply for Nike. However, the situation was also considerably different than it was just a decade earlier. For one thing, Nike now had some experience with factory disclosure. About 100 of its factories had been published on the WRC website for several years, and the company had not experienced any noticeable negative repercussions.

Nike executives also had more confidence in their monitoring abilities than in years past. It had implemented both SHAPE and M-Audits, it had several years' experience with FLA audits and reporting, it had a dedicated Labor Compliance Department and Compliance Field team that regularly reported back to Sourcing and Head Office, and it had now a global factory database with a fairly robust system for updating reports about each factory. In short, there was a feeling within the company that it had a better sense of what was going on in its supplier factories than in years past. There was also a belief, at least among the CR people at Nike, that the defensive strategy that had Nike battling media reports and NGOs

\footnotetext{
${ }^{65}$ Interview with Neil Kearney, General Secretary, International Textile, Garment and Leather Workers Federation, Toronto, 2006.
} 
investigations one factory at a time in isolation from other brands was not a realistic strategy going forward, particularly in apparel.

Apparel accounts for roughly one-third of Nike's business, but comprises the vast majority (579 in 2001) of its 750 supplier factories (compared to equipment (89 factories) and footwear (68) divisions). ${ }^{66}$ On the apparel side, Nike is often only one of many brands in a factory and, in many instances, it is not even the factory's major customer. This limits Nike's ability to pressure labor compliance issues and to track what is happening in the factories at any given time. ${ }^{67}$ By 2005 , Nike CR executives were talking a lot about the need for industry "collaboration" to monitor and address labor practice issues in the apparel industry.

They knew that, in fact, compliance officers from the many companies in the industry had been speaking with one another informally for years about conditions in shared factories. There was less secrecy about factory location within the apparel industry than many in the industry let on. Moreover, because of the phasing out of the Multi-Fibre Agreement in 2005 , the company anticipated that apparel would begin to consolidate in the way that footwear had, towards fewer factories and longer term relationships. In that environment, there would be even less secrecy about which companies were using which factories that there was today.

\footnotetext{
${ }^{66}$ There are various reasons for the proliferation of apparel factories, including different tariff and trade laws regulating the various industries, and the fact that apparel manufacturing is highly labor intensive and extremely sensitive to constantly changing fashion trends. See discussion in Locke, supra note 41, at 8-10. The Agreement on Textile and Clothing (the Multi-Fibre Agreement) governed trade in textiles between 1974 and January 1, 2005, when it was phased out.

${ }^{67}$ See, e.g., Locke, supra note 41, at 9 ("Nike works with numerous suppliers, most of whom are also working for other (often competitor) companies. Given that different apparel suppliers specialize in particular products or market segments, shifts in consumer preferences or fashion trends could translate into very short-term contracts with and/or limited orders from Nike. This alters both the level of influence which Nike has with these suppliers as well as its ability to monitor on a regular basis the production processes and working conditions of these factories.").
} 
Thus, as the Nike CR executives prepared their landscape analysis of the risks and benefits of full factory disclosure, "collaboration" became a key theme on the benefits side of the ledger. Caitlin Morris explains:

It's not that there is no business risk [from factory disclosure], but that the business risk relative to the benefits of collaboration is far lower, and there is a perception that the business risk is also mitigated by the fact that how we do business with factories, particularly in apparel, is different from how we did it ten years ago. As this whole concept of longer term relationships, consolidated supply chains, et cetera... if you're not doing the traditional, everyone's cashing for the lowest price, and you're trying to offer a more robust partnership or value to factory owners, then it's a little less of a corporate secret where you are, because you are not so worried about people coming in and stealing your capacity.

The belief within the $\mathrm{CR}$ group that a more effective strategy going forward would encourage industry collaboration about conditions and remediation in shared factories drove the company's decision to make full factory disclosure in its 2004 CR Report, as Morris explains:

If you're on average 10 to 15 percent in an apparel factory, 10 or 15 percent of that factory's volume, it's pretty hard to make change on your own. So if we really were serious about making change we were going to have to team up with other brands in a concerted way. So I would say the collaboration strategy came first, and flowing from the collaboration strategy was [the idea that] its going to be hard to collaborate if we don't know where we are, and that sort of drove transparency.

In the end, the arguments in favor of full factory disclosure were perceived by the Nike leadership to offset lingering concerns that the disclosure would harm the company.

The list was released in April 2005 and included all factories producing Nike branded items, but not Nike subsidiaries. This amounts to approximately 90 percent of Nike's supplier factories. In its 
announcement, the company emphasized the need for industry collaboration:

Our industry is at a crossroads. Individual companies, Nike included, now realize there are limits to what we can achieve independently. By being open with this list, and by providing the depth and breath of information in our CR report, we hope it will encourage others to join collaborative efforts. ${ }^{68}$

In the months that followed Nike's surprise disclosure, several of its leading competitors followed, including Adidas, Timberland, Puma, and Levi-Strauss, which is examined in the next section.

\section{Understanding LeVI-StRauss' Decision to Disclose its GLOBAL FACTORY LIST}

In 1975, Levi-Strauss ("LS") drafted a Code of International Business Principles, which included a commitment to "operating well above the minimum legal standard such that [the company's] conduct is and intentions are above question", and it included also a commitment respecting the treatment of workers: "The company subscribes to a single global philosophy of fair treatment of employees that is also consistent with local laws and practices." Consistent with the approach to codes at the time, the 1975 Code applied only to LS's own operations, not to its contractors. The promise to comply with local laws was also so a common feature of 1970s' corporate codes. But LS's code seemed to go one step further by indicating that compliance with laws was in addition to its promise to treat workers "fairly", and "well above the minimum legal standard".

These sorts of lofty statements of social responsibility are a common feature in the history of LS. For most of the $20^{\text {th }}$ century, LS enjoyed a relatively favored position amongst major American apparel companies in terms of its public reputation. Its reputation as a decent "corporate citizen" is usually traced back to its founder. Levi Strauss built the company from

${ }^{68}$ On-line at: http://www.nike.com/nikebiz/nikebiz.jhtml?page=25\&cat=activefactories 
a small operation with an interesting patented denim pant using a rivet into one of America's most iconic corporations. He was a significant philanthropist, and stories about his fair treatment of workers abound as historical anecdotes. ${ }^{69}$

The family heirs to the company, notably the Haas family, are similarly credited with maintaining a "do good" philosophy that permeated the management levels of the organization. Famously, in the 1950s, Walter and Peter Haas defied Virginian politicians and social norms by refusing to segregate black and white workers in their factories, a story that is still highlighted on the corporate website. ${ }^{70}$ When the company went public in 1971 , its prospectus made explicit reference to the "social responsibilities" of the company, according to Walter Haas, as a way of warning investors "that they weren't going to change". 71 The descendants of Levi Strauss took the company private again in 1985, "hop[ing] to revive the company's history of value-based decision-making."72

\section{The Business PARTNER TERMS OF ENGAgEMENT AND Guidelines FOR COUNTRY SELECTION}

However, its reputation for corporate decency did not shield LS from criticism when it began outsourcing its American production to foreign contractors in great quantities beginning in the late 1980s. In 1990, LS shut down one of its factories in Texas and shifted production to a contractor in Costa Rica, leading to the layoff of over 1000 employees in

69 Levi Strauss' personal and business history is recounted in a number of books, including Karl Schoenberger, Levi's Children: Coming to Terms with Human Rights in the Global MarketplaceS (Grove/Atlantic, 2002). As recounted by Schoenberger, his record as an employer was not impeccable: "like many other employers in North America in the late $1800 \mathrm{~s}$, he refused to hire Chinese workers, and he employed young girls in his factories and required them to work long hours in dangerous conditions" (at 35).

${ }^{70}$ Id. at 32 .

71 Id.

${ }^{72}$ L. Compa, T. Hinchliffe-Darricarrere, Enforcing International Labor Rights Through Corporate Codes of Conduct, 33 Colum. J. Transnat'l L. 663, 675 (1995). 
San Antonio. This move sparked a campaign against LS by the laid-off employees, who were mostly woman of Mexican origin, which turned into a public relations nightmare for LS, as explained by Schoenberger:

Some of these disgruntled former employees formed a militant labor group named Fuerza Unida and were still fighting back a decade later. The group launched a strident protest campaign with lawsuits, hunger strikes, demonstrations, and appeals for a boycott of Levi's products. Leader Irene Reynes wanted that the scorned ... workers would become Levis' "worst nightmare". Reynes and the other leaders journeyed from Texas to Levi Plaza ... and chained themselves to the front doors of corporate headquarters to draw attention to their cause... [To] Levi's executives spying down from the dark-tinted windows of their handsomely brownpanelled office buildings at Levi Plaza, the scene has tro have been painful to watch. Proud and aloof, Levi Strauss had very little experience being publicly vilified. ${ }^{73}$

In the one year period from 1991 and 1992, the percentage of LS products made by contractors jumped from 35 to 54 percent. $^{74}$ And many of these contractors were overseas, in developing economies.

For companies like LS, which sought to protect a brand image as a corporate social leader, the decision in the 1990s to move most of its production offshore, introduced significant new risks. One response was to revisit its global code of conduct and to update it for a new era in which the supply chain was considerably more global in scope and a global labor activist movement-that now included the media, human rights organizations, unions, church groups, and various other NGOs-had emerged which, with the use of the internet, had become extremely effective at discovering labor abuses and reporting them publicly in the form of damaging corporate campaigns.

Therefore, in September 1991, LS created a 14 member Sourcing Guidelines Working Group to develop a new set of guidelines for their

\footnotetext{
${ }^{73}$ Schoenberger, supra note 69 , at 49.

${ }^{74}$ Id. at 56.
} 
global supply contractors. The resulting Business Partner Terms of Engagement and Guidelines for Country Selection (Guidelines) was approved by LS's Executive Management Committee in March $1992 .^{75}$ With the new Guidelines, LS once again positioned itself as a leader in corporate responsibility by becoming the first multinational apparel company to confirm in writing its responsibility for labor practices in factories owned or controlled by its contractors.

The Guidelines included two parts, one applying to the selection of countries and the other setting standards expected of contractors. The content of the Guidelines was quite specific in terms of employment practices. It addressed child labor, prison and forced labor, wages and benefits, discrimination, and disciplinary practices. It also included a system of internal monitoring and unannounced audits, a tiered approach to resolution of problems, and the possibility for cancellation of orders for non-compliance. ${ }^{76}$

In explaining the need for the Guidelines, the company emphasized the risks associated with sourcing from abusive foreign employers:

As we expand our sourcing base to more diverse cultures and countries, we must take special care in selecting business partners and countries whose practices are not incompatible with our values. Otherwise, sourcing decisions could end up damaging the image of our brands and threatening our commercial success.

In the early days of the new Guidelines, the company announced it would stop contracting from Burma because of the country's human rights abuses, and it terminated contracts with more than 30 contractors in countries including Saipan, Honduras, Uruguay, and the Philippines for non-compliance. ${ }^{77}$ Early reviews by NGOs of LS's behavior under its

\footnotetext{
${ }^{75}$ Compa, supra note 72 , at $676-77$.

${ }^{76}$ The LS Guidelines were criticized for not expressly including the right to form and join unions or a right to collective bargaining, although it did include a broad statement noting that employees have a "right to free association", which the company asserted implied a right to collective bargaining. In later versions of the Guidelines, the right to "form and join organizations of their choice and to bargain collectively" was added.
}

${ }^{77}$ Compa, supra note 72 , at 678 . 
new code were generally favorable. It received accolades from many in the NGO community when in 1993 it announced dramatically that it would not source from China due to concerns about human rights abuses there, becoming the first American apparel company to adopt a "no China" position on the basis of human rights practices.

However, when the company later reversed that position in 1998, it was thrust back into the storm of corporate campaigns targeting labor practices. In a newspaper editorial in the summer of 1998, Medea Benjamin of the NGO Global Exchange challenged LS to be a leader in China, and to start by: "disclosing which subcontractor factories it will work with and what the wages and human rights conditions are in those factories", because "disclosure [was] critical to lifting the veil of secrecy under which many U.S. companies operate in China."78 LS did in fact disclose its global factory database, however not until October 2005. What happened at LS to cause its executives to make this information public?

\section{The Central Factory Database}

As with Nike, an important part of the story of factory disclosure at LS begins years prior to the actual disclosure, in incremental processes implemented by the company that created management confidence that factory disclosure would not harm the company. When LS introduced its Guidelines in 1991, it was sourcing from about 700 factories worldwide. There was no separate department created to manage the Guidelines. Responsibility for overseeing the Guidelines fell initially to Corporate Affairs, but it was the sourcing and quality control people in the actual regions where the factories were located that were expected to introduce their contractors to the Guidelines and to monitor compliance issues.

These people were not labor experts, and the Company did not start hiring full-time internal monitors until the mid-1990s. Nor did LS initially retain outside auditing firms to monitor compliance with the Guidelines. Thus, while the Guidelines were an important symbolic commitment to labor rights in its supplier factories, there was is the early years very little internal infrastructure in place to ensure its effective implementation. The

\footnotetext{
${ }^{78}$ M. Benjamin, A Riveting Announcement, San Francisco Guardian, June 10, 1998.
} 
company sent teams of internal auditors to conduct annual audits of the factories. It announced that the first round of audits found 95 percent of its supplier factories to be in compliance with the Guidelines or in need of relatively minor improvements. ${ }^{79}$ Contracts with 5 percent of factories were cancelled for non-compliance.

Prior to 1993, LS did not maintain a global factory database. No one at the San Francisco head office knew for sure how many factories were being used or where those factories were located. Sourcing issues were decentralized, delegated to the various regional offices. Thus, someone at the Asian sourcing office would know what factories were in use in Asia at any given time, subject to sub-contracting by the contractors about which the LS staff may not be aware. However, the Asian sourcing people would not know what factories were being used in the Americas, for example, and Head Office did not compile a master list. However, in 1993, as the company accumulated auditing reports from the first wave of audits under the Guidelines, a decision was made to create a single, central global database listing every factory sourcing LS product.

The database was built up over time, with audit results being inputted as they were completed. This process was aided considerably when, in approximately 1995, LS hired full-time Regional Managers for Europe, the Americas, and Asia, who were assigned the task of managing labor compliance issues and keeping the database current. Thereafter, throughout the mid and late 1990s, LS hired teams of internal factory assessors, who also were posted at the various regional offices. Today, there are 20 LS employees working full-time doing factory assessments, plus additional assessors who are not employees of LS, but who have been approved by LS after completing a week long monitoring program taught by LS officials. ${ }^{80}$

\footnotetext{
${ }^{79}$ Shoenberger, supra note 699 , at 64.

${ }^{80}$ Most of these external assessors are employed by independent auditing organizations. LS does not approve entire firms or organizations because, according to Kobori, quality varies considerably among individuals. Therefore, LS issues approvals of external auditors only on an individual basis.
} 
Today, the LS assessors and the Regional Managers are situated in the Code of Conduct Department, which was established in 2000, and is currently headed by Michael Kobori. Kobori works from the company's San Francisco Head Office and holds the title Vice-President, Global Code of Conduct. The three Regional Managers report to Kobori. Kobori reports to the Senior Vice-President of Global Sourcing, which means that the Code of Conduct Department is integrated with the business operations and part of Global Sourcing. This reporting line has been in place since about 2000 .

The results of audits conducted by the internal and external monitors are compiled by LS officials and entered into the factory database at regular intervals. Auditors working either for or on behalf of LS must complete a detailed 40 page form that measures a factory's compliance with the Guidelines as a precondition for LS adding the factory as a supplier. That information is then entered in the central global database, which can be accessed by sourcing staff, other auditors engaged by LS, and LS executives and employees in the Corporate Code of Conduct department. Thus, since the late 1990s, as at Nike, LS officials at Head Office have been able to instantly access a complete factory database that includes a vast array of information about labor practices in each factory and this database in being regularly updated by factory assessors whose job it is to visit factories.

\section{THE INTERNAL INFORMATION HiGHWAY}

Information about factory labor practices travels through the company in other ways as well. Both Nike and LS acknowledged that they sometimes learn about labor problems in their supplier factories from NGOs. Both companies have concluded that it is in their best interest to take those issues seriously and to investigate the allegations before they become fodder for negative public relations campaigns. If a complaint comes into Kobori's office, he can instantly look up the factory in the database and view the most up to date information about the factory's compliance

history. Kobori explained how he would respond to a complaint received at his office about an alleged violation of the LS Guidelines:

...my first reaction is to send that report in as much detail as I can to the Regional Manager, who will sit with the assessor, and they'll 
go into the next phase of the investigation. It's a pretty standard procedure.

Once the investigation at the factory is complete, the results would usually be entered into the database, and the NGO, or whoever first contacted the company about the problem would receive a reply from the company.

An example of this process is described in a report prepared by the UK based multi-stakeholder, Ethical Trading Initiative (ETI) in 2003, which LS joined in $1999 .^{81}$ In August 2003, a group of NGOs, including the Central America Women's Network (CAWN), the Workers Support Centre (CAT), and Toronto-based Maquila Solidarity Network contacted LS about a series of incidents in a Tarrant Ajalpan factory in Puebla, Mexico that violated LS's Guidelines. This letter officially initiated the ETI code violation procedure. LS requested the NGOs provide it with more information, and it sent its Regional Code of Conduct Manager to Puebla in mid-September to meet with the CAT, the factory workers, and the factory owners. LS requested that the owners of the factory permit an independent audit of the factory, to be conducted by the auditing firm Verite. That request was denied, which was itself a violation of the Guidelines. LS also received a report on the factory prepared by the WRC which appeared to confirm other violations of the Guidelines. LS wrote letters to the local government expressing concern over the labor practices in the factory, and finally, in October 2003, after the factory owners had indicated it would not work with LS any longer, LS pulled its work from the factory.

\section{LEVI STRAUSS AND INDEPENDENT MONITORING}

One criticism from NGOs and labor organizations that dogged LS even after it began its factory monitoring process was its continued refusal to permit independent monitoring and for its lack of public transparency about audit results. For example, in 1995 and 1996, a Canadian Catholic NGO called Development and Peace investigated factories supplying LS

\footnotetext{
81 Ethical Trading Initiative, Addressing Labor Rights Violations at Tarrant Ajalpan Mexico Using ETI's Complaints Procedure (May 2004), http://www.ethicaltrade.org/Z/lib/2004/05/codeviol-mex/index.shtml .
} 
products in Honduras and the Philippines and found various violations of LS's Guidelines. ${ }^{82}$ Development and Peace collected and forwarded over 100,000 signed postcards to Robert Haas asking the company to permit independent monitoring of the factories. The organization received a dismissive response from the President of Levis Canada, Gordon Shank, who asserted that LS's own employees are in the best position to monitor compliance with the Guidelines. ${ }^{83}$

Various other NGOs and labor activists also began to target LS and its refusal to allow independent monitors to investigate its factories and to publicly report back on the findings. One of the most vocal critics of LS was the Dutch based NGO, Clean Clothes Campaign (CCC). In May 1998, it released a lengthy and detailed report into alleged working conditions at factories supplying LS products ${ }^{84}$. LS responded by challenging many of the conclusions in the report. ${ }^{85}$ One of the principle demands, or at least suggestions for improvement, set out by the CCC was that, if LS wished to preserve its image as leader in the CSR movement, it should take the next step and permit independent monitoring and public reporting of the results of those audits.

However, through most of the 1990s, LS refused to open up its supplier factories to outside scrutiny. In contrast to Nike, LS did not initially participate in President Clinton's AIP initiative, which because of the involvement of various union and church groups was widely expected to result in a system that required some form of independent monitoring.

${ }^{82}$ Development and Peace, Noveca Industries: A Case Study in the Philippines, (1996). See also, Schoenberger, supra note 699 at 71-72; Clean Clothes Campaign, Levi Strauss \& Company: Corporate Profile and Case Material (Apr. 30, 1998), http://www.cleanclothes.org/companies/levi5-5-98.htm\#focus.

${ }^{83}$ Id. at 72.

${ }^{84} \mathrm{Id}$.

${ }^{85}$ A point by point response was sent to the CCC by Patrick Neyts, who was then the Director of environment, health, and safety for Levi's in Europe. The letter is not published on either the website of the CCC or LS, however, CCC does reference the letter and some of the Neyts responses in a subsequent reply to Neyts: Levi Strauss update from the CCC (Dec. 22, 1998), http://www.cleanclothes.org/companies/levi98-12-22.htm. 
Shoenberger suggested that LS's refusal to participate in the AIP was in large measure due to its "fundamental aversion to transparency". 86 This is an overgeneralization. While it is certainly the case that sourcing executives were averse to having a public spotlight shone on their supplier factories, Patrick Neyts, head of the Code of Conduct Department in the mid-1990s had begun making the case internally for factory disclosure as a way to enhance and protect the corporation's reputation as an ethically responsible company. As noted earlier, Neyts gathered a list of a competitor's supplier factories as a way to convince LS executives that the company's supply chain was not a secret. ${ }^{87}$

The FLA model that resulted from the AIP negotiations did in fact require independent monitoring, but of only a very small percentage of supplier factories, and while participating companies were required to disclose their factory list to the FLA, there were strict requirements that this information not be disclosed publicly or to other participating companies.As it turned out, therefore, the FLA was not very threatening, and many of LS's main competitors had signed on, including Nike, Reebok, Phillips Van Heusen, and Liz Claiborne. LS had explained its refusal to participate on the basis that it saw no benefit to doing so, since its internal monitoring system and its Guidelines were working fine. But in 1999, LS joined the FLA, thereby agreeing to open up its factories to outside inspectors for the first time, albeit in a limited way. Joining the FLA was one of several signs in the late 1990s that LS was becoming more willing to open up its model to public scrutiny, and to engage outsiders in the process, including NGOs and labor organizations.

As noted earlier, LS joined the ETI in $1999 .{ }^{88}$ In 1998, it permitted several NGOs to participate in a pilot project involving an assessment of

\footnotetext{
${ }^{86}$ Shoenberger, supra note 69 , at 221 .

87 Interview with Patrick Neyts, Toronto, 2007.

${ }^{88}$ LS was suspended from the ETI in December 2006 for refusing to comply with the "living wage" requirement in the ETI's Code, and in February 2007, LS resigned from the ETI because it felt it could not agree to this requirement. See for details, Press Release, ETI, Resignation of Levi Strauss \& Co. from ETI, (Feb. 5, 2007) http://www.ethicaltrade.org/Z/lib/2007/02/levistrauss2-stmt/index.shtml.
} 
its Guidelines and monitoring processes at a factory in the Dominican Republic. The NGOs were permitted to interview the workers, and they found that while the workers were generally treated decently and in accordance with the Guidelines and labor laws, few were aware of the Guidelines or their legal employment rights. ${ }^{89}$ LS made this report public, including a comment by one NGO that LS's monitoring model needed to be accompanied by "independent monitoring". 90 Kobori later discussed this project, including the comments of the NGOs, at a 1998 conference of the industry-based organization, Business for Social Responsibility.

Kobori explained this gradual movement towards greater transparency in the late 1990s as an evolutionary process based on experience:

In the mid-1990s, there was a real resistance for a lot of companies to even having a code of conduct, to even adopting standards. And I would say in the past 10 years...everything has changed to the point that where if you don't have a code of conduct, people are asking why? I think that there was also resistance to independent monitoring, there was a mind-set, or a perception in the industry: "Hey, we're doing this, we know how, what do we have to learn from anyone else?" And I think over the years, we and everyone else in the industry that does this work, we are learning as we go, because it hasn't been done before. So there's, I think, just an evolution back in the mid 1990s, that...there's a broader external set of stake-holders here that can actually help us in doing this work.... I don't think it was any big "ah-ha" moment. I think it was just a combination of factors that eventually moved companies or caused companies to evolve their thinking in this area, to be more dynamic, to be more open to external engagements. ${ }^{91}$

\footnotetext{
${ }^{89}$ Schoenberger, supra note 699 , at 217-219.

${ }^{90}$ Id. at 221.

${ }^{91}$ Interview, Kobori, supra note 2.
} 
In his address to the BSR conference, Kobori encouraged business leaders to "be completely transparent", and not to be afraid "to take risks", "because you might learn something that will make you better."92

\section{The DeCision to DisClose THe FACTORY LiST}

However, despite these strong sentiments in favor of transparency, the notion of voluntarily disclosing the entire factory database was not one being seriously considered at LS as the new century dawned. According to Kobori, factory disclosure was recognized as one of many possibilities that the company could explore, but it was not a move that had been formally evaluated. That changed in the spring of 2005 when Nike suddenly released their global factory database on its website. Kobori indicated that the Nike announcement was a stimulus for serious discussion about factory disclosure at LS.

The idea of following Nike's lead was considered at the Code of Conduct's mid-year management meeting in the summer of 1995. The idea of factory disclosure was then considered using a decision-making model known as the Levi Strauss \& Company Way, which required as a first step that the idea be given serious attention as a possible course of action, followed by a process of intelligent exploration that included researching the "pros and cons" of factory disclosure, including by means of discussions with competitors and other stakeholders.

One of the primary perceived benefits of factory disclosure was that it would enable greater collaboration between brands to reduce duplication of monitoring. According to Kobori, duplication of monitoring in the apparel industry detracts considerably from the important task of trying to plan a strategy to address problems:

... we all began to realize, guess what, we're in shared factories, we're all sending monitors there, suppliers are getting visited by a monitor every two or three weeks. There's more time being spent receiving these monitors and showing them around than actually

\footnotetext{
${ }^{92}$ Schoenberger, supra note 69 , at 220.
} 
making the improvements in the factory... As an industry, at best, we are spending 20 percent of our resources on creating the change that we need to be sustainable going forward...[and] ...probably 80 percent of our time on monitoring.

Kobori had come to believe that it was best to "empower" the field staff, who were out there in the factories, to move forward with the discussions they were already having with auditors and monitors representing other apparel companies about how to work on joint remediation plans and how to reduce duplication of audits. Factory disclosure was perceived as a way to do this.

Factory disclosure was presented as an idea to Sourcing and to some of the suppliers and licensees, as well as to senior company officials. There was some initial resistance within Sourcing, and from some exclusive LS licensees who claimed they did not want to be included in the list. However, according to Kobori, most suppliers were pleased to be included on the list, because the fact that they had passed LS's Terms of Engagement assessment was perceived as positive marketing. One supplier called Kobori complaining that it had not been included on the list. By early fall, 2005, LS had decided to disclose its global factory database. The database already existed of course, and after some checking for accuracy of names and addresses, the factory list was released publicly in October 2005 on the company's website. ${ }^{93}$

\section{VOLUNTARY FACTORY DISCLOSURE: CONCLUSIONS, LESSONS, AND IMPACTS SO FAR...}

At the outset of this paper, I characterized regulated factory disclosure as a "risk virus" which, if injected into the corporate "bloodstream" of an apparel company, would cause the corporation to introduce measures to

\footnotetext{
${ }^{93}$ Available on-line:

http://www.levistrauss.com/Citizenship/ProductSourcing/Issues/FactoryNamesAndLocati ons.aspx
} 
control the risk. One objective of this paper was to explore whether there are traits shared by companies that disclose their factory lists voluntarily that appear to confirm the normative expectations of factory disclosure advocates about how the disclosure virus if introduced by regulation would by managed by apparel companies. What have we learned about the potential contribution of factory disclosure as a policy to improve labor practices within global apparel supply chains?

An obvious initial observation is that both companies disclosed their factory lists only once company officials believed it was relatively safe to do so. To reach this point of comfort, a number of important steps had been taken over preceding years. Firstly, both companies had introduced codes of conduct over a decade prior to the factory disclosure. This gave the companies time to learn and experiment with defining the content of the code, with code monitoring and remediation, and with the various ways in which to present information about the code to a skeptical public and stakeholders. Both companies had experienced significant growing pains in this process and had been targeted by NGOs in negative publicity campaigns. However, that process enabled the companies to become more comfortable in dealing with their critics, to the point that some NGOs acknowledge a visible shift in the extent to which Nike and LS have in recent years been prepared to dialogue with them and share information about labor problems in their factories. ${ }^{94}$

Another key measure was the introduction of factory auditing systems. Neither company claims the ability to monitor every factory on a regular basis. However, audits are now sufficiently regular that, in the perception of the companies, the risk of being caught completely unaware of abusive labor practices in a supplier factory has been reduced to a tolerable level. In addition, since senior compliance staff are now more prepared to dialogue with NGOs when labor problems are discovered, the companies are more confident that they will be evaluated by NGOs by their response

\footnotetext{
${ }^{94}$ Discussions with Bob Jeffcott and Lynda Yanz, Maquila Solidarity Network, Toronto, 2007.
} 
to problems rather than merely on the basis that problems exist. ${ }^{95}$ It is relevant too that both companies primarily source their own factories rather than use sourcing agents. This removes the step, and associated risk, of having to depend on an intermediary to track the factories.

The creation of a global factory database was crucial development at both companies. This is a key moment in the risk management process not only because it enables better tracking of events and practices in specific factories, but also because it emphasizes to employees in sourcing, production, and labor compliance that every factory is treated as a distinct unit that will be monitored and measured against defined labor standards. The introduction of a global factory database also provides a looking-glass through which senior officials at head office can observe the goings on in particular factories and regions. It is an important part of an information system that enables a company to track what is happening in its supplier factories, and it signals to field staff that they too may be monitored.

Both companies have also developed a quite robust system for gathering and conveying information up and down the links from head office to factory level. This system began with the appointment of dedicated senior level staff who are responsible for monitoring labor practices in supplier factories. Both companies had created labor compliance departments by the turn of the century, staffed by senior Vice Presidents and teams of internal compliance auditors. Within the labor compliance departments, there is also now a clear chain of command. Complaints received from external sources alleging problems in a supplier factory can now be quickly relayed from head office officials to field staff, who can

\footnotetext{
${ }^{95}$ This development is reflected in the decision of the companies to disclose incidence of non-compliance with their codes of conduct. The strategy of admitting labor problems, but pledging to work with NGOs to plan corrective measures is a trend in the apparel industry, at least among leading brand-based companies (including, for example, The Gap), although one that also has not been picked up by Canadian-based apparel and retail companies. Exceptions are MEC (see MEC, Marking Our Route: 2005 Accountability Report, http://images.mec.ca/media/Images/pdf/MEC_Accountability_Report_v1_m5657756983 0609369.pdf.) and The Hudson's Bay Company (see HBC, Monitoring Our Supply Chain, http://www.hbc.com/hbc/hbc_csr_eng/es_monitoring.html\#AUDIT (last visited Nov. 3, 2007).).
} 
then investigate the situation first-hand and relay their report back to head office.

There are, to summarize, signs that Nike and LS introduced the sorts of measures factory disclosure advocates anticipate will become more common under a system of industry factory disclosure. Systems for tracking which factories are being used, better communications system for conveying information about labor practices in specific factories up to responsible corporate officials, and more dynamic factory monitoring systems were developments that occurred at both companies which contributed to a level of comfort that by 2005 enabled factory disclosure to occur.

Both companies also claim to support the idea of linking performance and compensation evaluations to the compliance performance of factories, although I heard different opinions about how this should be done and which employees should be included. Nike places primary responsibility for factory compliance on the Sourcing agents, since it is the Sourcing people who the most direct business dealings with the factory owners. However, Nike is still wrestling with how to formally incorporate labor compliance into the evaluations of Sourcing employees.

According to Morris, there are informal pressures on Sourcing agents to bring their factories into compliance. For example, if a factory remains "D-Rated" for a number of months, this will drive "a pressure conversation" in which the agent is asked, "what are you doing about this factory, and why are we still with them?" Nike would like to develop a human resource strategy that more formally incorporates labor compliance into the evaluations of Sourcing personnel. Morris noted, however, that doing so is a challenge because the company recognizes that there are "root causes" for non-compliance that are often completely out of the control of Sourcing personnel. "Root cause" analysis is something that labor NGOs have been pushing corporations to think about for years. It

\footnotetext{
${ }^{96}$ As an example, she explained that a t-shirt design may be changed at the last minute by Nike design people, which causes a factory to employ more overtime to meet the delivery deadline. An audit of that factory may find a breach of hours of work limits, but that would not be the Sourcing agent's fault.
} 
appears that the discourse at least is beginning to seep into management systems.

Interestingly, Nike does not evaluate the Compliance staff on factory compliance. Rather, the job of Compliance staff is to observe, investigate, report back, and to help formulate remedial plans. Morris explained that evaluating Compliance staff on factory compliance records would lead to a "poor set of incentives". LS, on the other hand, does evaluate its assessors on the basis of factory compliance levels. This system evolved primarily in the past few years. According to Kobori, the internal assessors, who are located in the Code of Conduct Department, and the Sourcing employees are responsible for monitoring compliance with the Guidelines, and for developing corrective plans whenever violations are discovered. If factories fail to improve over time, that failure reflects poorly on the assessors, the Regional Manager, and responsible Sourcing workers. ${ }^{97}$

Perhaps the most interesting observations flowing from this study relate to what has happened since these companies disclosed their factory lists. Neither company reported any adverse effect that they could link to the disclosure. There was not a sudden increase in reported incidents of laborrelated problems, and there have not been problems related to competitors using the information in ways harmful to the companies. It is too soon to judge whether factory disclosure will tend to encourage longer term supplier relationships. Kobori believes that factory disclosure introduces an important element of accountability at the factory level "that will encourage factories to maintain positive working conditions and begin to

${ }^{97}$ Kobori explained the rationale as follows:

In my view, if the factory fails to meet the initial action plan, it means that the assessor either had not communicated the messages clearly enough, or has not followed up with them sufficiently. Now, if they fail to meet it, it's up to the assessor to enlist the support of his or her business partner on the sourcing side to send a strong message to the factory. If the factory still doesn't get it, then it's up to the assessor and the (Sourcing) business partner to escalate. So there's a process in place, so it really is the assessor, and it's also the Regional Manager, who need to work together to make sure that the factory performance is improving. 
foster greater factory ownership of the compliance process". However, more time will be needed to assess the effects, if any, on the factory owners and on the actual conditions of work in the factories.

Most interesting is the effect that the disclosure has had in terms of collaboration and engagement both within the apparel industry and between the companies and external actors. Both LS and Nike contacted competitors after they had disclosed their factory list and encouraged them to review the list and identify shared factories with the hope that further discussions could follow about possible joint actions. For example, Caitlin Morris explained this process as follows:

...we picked up the phone and literally started saying, "Hey Levis, hey so and so, we've published our list, could you look at it, and even if you don't want to be transparent publicly, would you share with us which factories we share. It wasn't until we started doing that on a systematic basis that I could build a map, and go, oh, we've now identified 30 percent overlap in our supply chain with the following 15 brands.

Kobori added that LS also contacted NGOs after they released their list:

After we made our list public, we reached out directly to a lot of other brands, as well as NGOs... We said, here's our list, if you're in any of these factories, if you're already monitoring these factories, tell us. So we can start to work together and collaborating on the monitoring and on the remediation. And maybe if, you know, you're doing some training in the factory and we're doing some training in the factory, maybe we can get together on that... We got a very strong response, everyone was interested.

These discussions have led to meetings of brands, monitors, and factories.

LS has been convening these meetings, which have taken place in five different countries, with the intention of discussing ways to share information and collaborate in monitoring, training, and remediation. Nike is participating in those meetings, as are a variety of other apparel brands, and Kobori indicated that he envisions NGOs becoming part of 
these discussions in the future. Discussions are cautious at the moment, as the companies become comfortable with one another. There are also concerns about the possible limits of this sort of collaboration under U.S. anti-trust laws, an area that needs further exploration. ${ }^{98}$ If anti-trust laws prevent companies from working together towards sensible solutions to labor abuse problems, then those laws may need to be revised as surely this was not the legislative intent.

\section{CONCLUSION}

So, is factory disclosure regulation worthy of serious investigation? I would conclude that it is. If other companies were to respond to the "risk" of having a transparent global supply chain by introducing measures similar to those witnessed at Nike and LS-developing and maintaining supplier factory databases, expanding factory monitoring capabilities, establishing dedicated labor compliance personnel and clear chains of command that encourage quick information sharing about factory conditions - then factory disclosure would contribute positively to the challenge of how to discourage abusive labor practices, at home or abroad. The fact that factory disclosure appears also to be encouraging collaboration within industry and between industry and external labor organizations in the hopes of identifying more efficient and effective long term solutions also supports a move towards factory disclosure regulation.

Moreover, there is little evident downside risk from regulated factory disclosure. No doubt, factory disclosure increases the potential that the public may learn about abusive labor practices within a supply chain. However, while it is easy to understand why apparel companies and retailers would like to keep that sort of information from the public, there is no policy justification for allowing them to do so. The fact that more and more companies are now voluntarily disclosing their factory lists proves that it is not economically or practically impossible to do this. True, smaller companies than Nike, LS, and Timberland will not have the same resources to invest in factory disclosure and factory monitoring. But factory disclosure need not cost companies millions of dollars. It does

${ }^{98}$ See S. Murray, Alliances Heed Anti-Trust Traps, Financial Times, Jan. 5, 2006 
require companies using sourcing agents to ensure those intermediaries pass along the contractor list, but companies should be requiring this anyways-otherwise they are ignoring what happens in their supplier factories altogether. ${ }^{99}$

The argument that factory address is somehow proprietary and competitive is also unconvincing. As noted, for experts working in the apparel sourcing industry, it is not difficult to learn which factories specific companies are using if that information is perceived as useful. Indeed, factory owners are happy to brag about this information. The emergence of initiatives such as the Fair Factories Clearinghouse is evidence that, within the apparel industry, there is a willingness to share information about supplier factories. It is the risk associated with sharing this information publicly that concerns many apparel companies and retailers.

As a labor policy, factory disclosure also has the benefit of neutrality in terms of the content of substantive labor standards. Claims that a Canadian or American law requiring factory disclosure is protectionist do not withstand scrutiny. Factory disclosure imposes no substantive standards. Rather, it is intended only to facilitate monitoring of labor practices-what employment standards employers are expected to adhere too remains a question for national governments, international law, and bargaining between factory owners and their employees and their unions, and apparel companies, increasingly in the form of corporate codes of conduct.

Factory disclosure regulation is an incremental approach to addressing labor practices in the global apparel industry, to be sure. And details about how a regulatory model would operate and be enforced in practice would need to be worked out. Since many companies still do not pay attention to which factories supply their product, it may make sense to give companies a reasonable amount of time to prepare for the disclosure. But these are details. As Kobori noted, a law requiring factory disclosure would at this point "level the playing field", and more importantly, "for society as a

99 See for example, Roots Canada, Workplace Code of Conduct (June 2006), http://www.roots.com/new canada/html/about_us/RootsCodeofConduct.pdf (requires their contractor factories to "disclose the name and address of every subcontractor used in the production of Roots garments and products"). 
whole", it would "do what a law is designed to do, which is to better the common good." 